\title{
Aspects of the Mean Wintertime Circulation along Australia's Southern Shelves: Numerical Studies
}

\author{
Mauro Cirano \\ Centro de Pesquisa em Geofísica e Geologia, Universidade Federal da Bahia, Salvador, Bahia, Brazil \\ JOHN F. MidDLETON \\ School of Mathematics, University of New South Wales, Sydney, New South Wales, Australia
}

(Manuscript received 22 April 2003, in final form 14 August 2003)

\begin{abstract}
A high-resolution numerical model is used to study the mean wintertime shelf-slope circulation between the Gulfs of South Australia and the west coast of Tasmania. The mean downwelling-favorable winds for the region result in a continuous eastward coastal current (CC) extending from Cape Leeuwin to the eastern coast of Tasmania. The magnitude of the CC is generally largest over the shelf break, has speeds of more than $40 \mathrm{~cm}$ $\mathrm{s}^{-1}$ [transport $2.4 \mathrm{~Sv}\left(\mathrm{~Sv} \equiv 10^{6} \mathrm{~m}^{3} \mathrm{~s}^{-1}\right)$ ], and is generally in good agreement with observations. The relative importance of the Leeuwin Current, zonal winds, and density gradients to the shelf circulation is established. Within Bass Strait, the eastward circulation is in good agreement with observations and simple models show that about $30 \%$ of the transport arises from local winds and the remainder from the CC. The total transport through the strait $(0.95 \mathrm{~Sv})$ is shown to be controlled by sea level on the east coast of Tasmania. A current of up to $10 \mathrm{~cm} \mathrm{~s}^{-1}$ is also found to flow from Tasmania to Esperance in the far west (transport $6.8 \mathrm{~Sv}$ ) and to be centered within the permanent thermocline (depth $600 \mathrm{~m}$ ) and near the shelf slope. This Flinders Current arises from the equatorward Sverdrup transport but is also fed by the "Tasman outflow" that enters the region off of the southern tip of Tasmania. A sensitivity study shows that dense water formation occurs off of Spencer Gulf and the cascade to depths of $250 \mathrm{~m}$ is in qualitative agreement with observations. Dense water formed near the coast can enhance the $\mathrm{CC}$ by up to $5 \mathrm{~cm} \mathrm{~s}^{-1}$. Suggestions for future modeling and observational studies are made.
\end{abstract}

\section{Introduction}

The aim of this work is to provide a first-order description of the mean wintertime downwelling-favorable shelf and slope currents between the gulfs of South Australia and the west coast of Tasmania (Fig. 1). To this end, a high-resolution numerical model of the region will be nested inside the results from a global ocean model and forced with wintertime averaged winds. A study has also been made of the summertime circulation and a comparison with the winter results is made there (Middleton and Platov 2003).

During winter, the wind stress for the region is characterized by an eastward mean $(0.07 \mathrm{~Pa})$ and by a variability $(0.12 \mathrm{~Pa})$ that arises from the passage of storms and cold fronts (e.g., Schahinger 1987). Time-varying winds lead to coastal-trapped wave (CTW) generation (Middleton and Black 1994), and observations for the region indicate the rms variability can be on the order

Corresponding author address: Dr. John F. Middleton, School of Mathematics, University of New South Wales, 2052 Sydney, New South Wales, Australia.

E-mail: john.middleton@unsw.edu.au of or larger than the mean (see Table 1 below). Tidal currents can also be large in the gulfs and Bass Strait, although the study by Platov and Middleton (2000) indicates that the rectified currents are small $\left(<5 \mathrm{~cm} \mathrm{~s}^{-1}\right)$. In this study, the effects of tides, weather-band forcing, and CTW generation will not be considered. Our aim is to focus on the (possibly) steady circulation that can arise from forcing by wintertime averaged winds.

A number of observational studies have been made and point to the existence of a wintertime shelf current that flows from Cape Leeuwin to the southern tip of Tasmania (a schematic of the currents for the region is shown in Fig. 1). At the western most part of the domain it is known as the Leeuwin Current and off Albany, the acoustic Doppler current profiler (ADCP) observations of Cresswell and Peterson (1993) show that it enters the Great Australian Bight (GAB) region with speeds of up to $80 \mathrm{~cm} \mathrm{~s}^{-1}$ over the shelf break (the 200-m isobath). The analyses of Herzfeld (1997) suggest that the influence of the Leeuwin Current warm water mass diminishes near the middle of the GAB $\left(\sim 130^{\circ} \mathrm{E}\right)$. Moreover, the coastal currents (CC) east of $130^{\circ} \mathrm{E}$ are likely driven by the onshore Ekman transport of the predominantly 


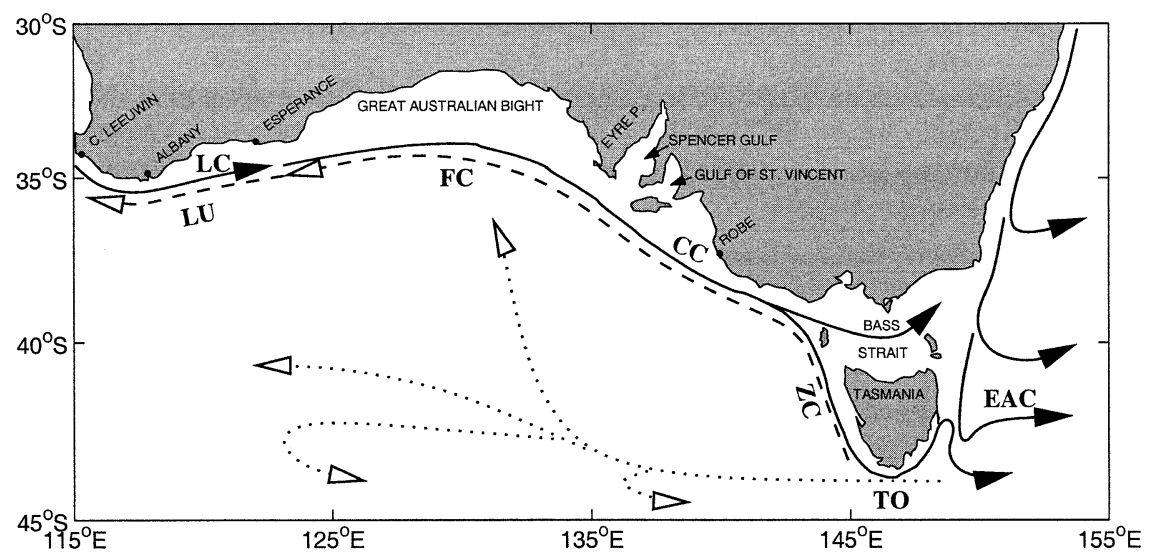

FIG. 1. A schematic of the wintertime circulation of the region. Solid lines are the surface currents: Leeuwin Current (LC), coastal current (CC), Zeehan Current (ZC), and East Australian Current (EAC). Dashed and dotted lines are the (largely) subsurface currents: Flinders Current (FC), Leeuwin Undercurrent (LU), and Tasman outflow (TO). The small islands from left to right are Kangaroo Island, King Island, and the Fourneaux group.

zonal winds, which act to set up coastal sea level (e.g., Church and Freeland 1987). In addition, the return flow of this onshore transport, coupled with intense cooling, is thought to be the cause of the deep surface mixed layer and downwelling $(200-400 \mathrm{~m})$ found throughout the region. Such downwelling is illustrated by surveys of Rochford (1986) and Godfrey et al. (1986) and the CSIRO Atlas of Regional Seas (CARS; Ridgway et al. 2002). The cooling and evaporation also leads to the development of dense water within the coastal waters of Spencer Gulf and Robe.

Off South Australia, current-meter data (Provis and Lennon 1981; Hahn 1986; Schahinger 1987) indicate mean alongshore currents to the southeast with speeds of $15-30 \mathrm{~cm} \mathrm{~s}^{-1}$. Within Bass Strait, the data of Baines et al. (1991) indicates a generally eastward flow and a northward jet near the northeast corner of Tasmania.

Off the west coast of Tasmania, the CC is named the Zeehan Current (Baines et al. 1983), and observations (Lyne and Thresher 1994) indicate a southward shelf current with mean speeds of up to $30 \mathrm{~cm} \mathrm{~s}^{-1}$. In deeper water, a northward current was found. We show below that the northward current forms part of the Flinders Current (FC) and that it flows from the southern tip of Tasmania to Cape Leeuwin. Middleton and Cirano (2002) have shown that to the west of Robe, an FC should arise from the equatorward Sverdrup transport within the southern ocean. Upon reaching Australia's southern shelves, this transport is deflected to the west in a deep $(600 \mathrm{~m})$ upwelling favorable bottom boundary layer.

The purpose of this study is to determine the cause and extent of the CC and FC with particular focus on the region between Cape Eyre and Tasmania. Does the East Australian Current affect the circulation within Bass Strait and on the west coast of Tasmania? The observations of Rintoul and Sokolov (2001) indicate a deep westward-flowing current at the southern tip of Tasmania. Does this current affect the FC? In addition, what is the relative influence of winds, the Leeuwin Current, density, and dense water formation on the circulation? The results will be used to make suggestions for future modeling efforts and observational studies.

The numerical model is described in section 2 along with the spinup and a brief overview of the results. In section 3, details of the circulation for the South Australian region are discussed along with the role of the Leeuwin Current and density field. An examination of the global Ocean Circulation and Climate Advanced Model (OCCAM) results is made in the appendix. In section 4, the circulation in and around Bass Strait is explained using simple models of CTW propagation and wind forcing. Where possible model results are evaluated against observations. In section 5, a summary and discussion are presented along with suggestions for future studies.

\section{The ocean model and spinup}

The model consists of a high-resolution version of Princeton Ocean Model (POM; Blumberg and Mellor 1987; Mellor 1998) nested inside the $1 / 4^{\circ}$-resolution OCCAM (Webb et al. 1998). The latter is to provide depthintegrated transports at the boundaries of the high-resolution regional model as well as the initial temperature and salinity fields. The model domain (Fig. 2) will allow for the influence of the Leeuwin Current in the west and the East Australian Current in the east.

\section{a. The model grid and initial thermohaline field}

The curvilinear grid adopted (Fig. 2) has $63 \times 173$ cells in the offshore $(x)$ and alongshore $(y)$ directions and highest resolution over the shelf-slope region. The 


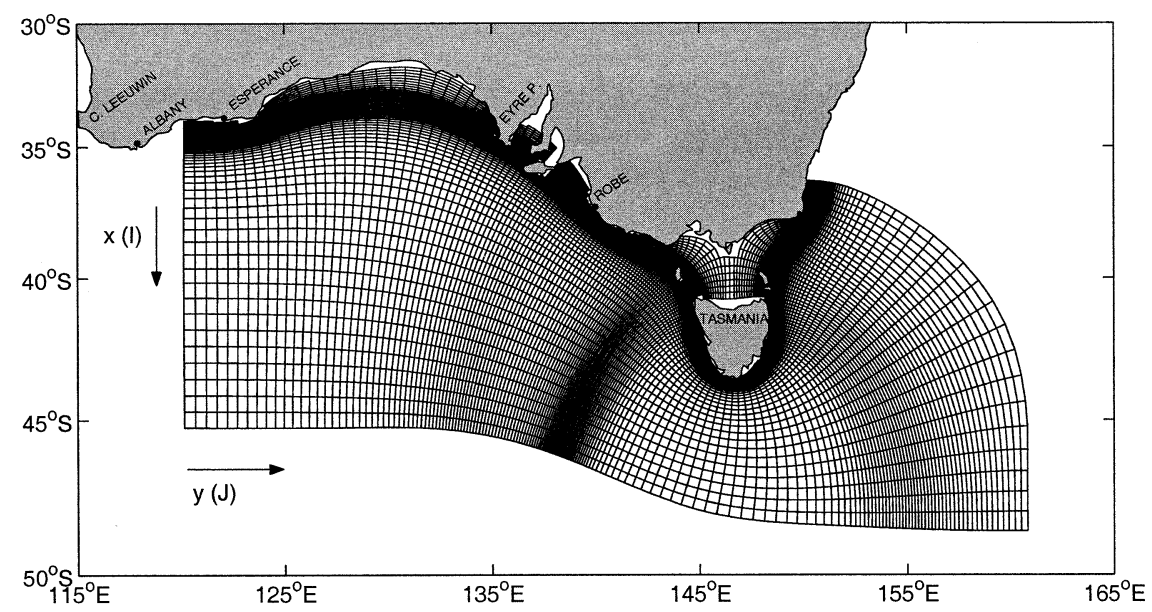

FIG. 2. The horizontal curvilinear grid with 63 cells offshore (the $x$ or $I$ direction) and 173 cells alongshore (the $y$ or $J$ direction).

alongshore grid cells vary between 10 and $20 \mathrm{~km}$ while the offshore grid cells vary between 2 and $7 \mathrm{~km}$. The vertical grid has $32 \sigma$ layers. The topography was based on the $1 / 120^{\circ}$ dataset from the Australian Geological Survey Organisation (AGSO) and minimum depths are 20 and $5400 \mathrm{~m}$.

The model was initialized using the wintertime thermohaline field obtained from OCCAM. The OCCAM field itself was initialized with Levitus et al. (1994) and Levitus and Boyer (1994) data and surface fluxes were determined by relaxing the top model layer to the seasonal Levitus climatology. Meteorological fluxes of heat and freshwater were not used. The wintertime density field from OCCAM and the CARS atlas is illustrated for a meridional section near Kangaroo Island (Fig. 3). The observations indicate the water nearest the coast to be up to $\sim 0.5 \mathrm{~kg} \mathrm{~m}^{-3}$ denser than in OCCAM. This dense water arises from the loss of heat and evaporation expected for the near coastal regions (Nunes-Vaz et al. 1990; da Silva et al. 1994; Josey et al. 1996; such dense water formation was not modeled in OCCAM but will be modeled here through an exploratory sensitivity study in section 4). Encouragingly, both the CARS and OCCAM density fields indicate the existence of downward sloping isopycnals near the shelf slope, a result attributed to wind-forced downwelling (e.g., Rochford 1986).

An attempt was made to initialize the nested model using hydrostatically adjusted CARS temperature and salinity fields and OCCAM boundary transports (see below). However, the model was found to become numerically unstable in deep water. No such instabilities were found using the OCCAM thermohaline fields and these were therefore adopted.
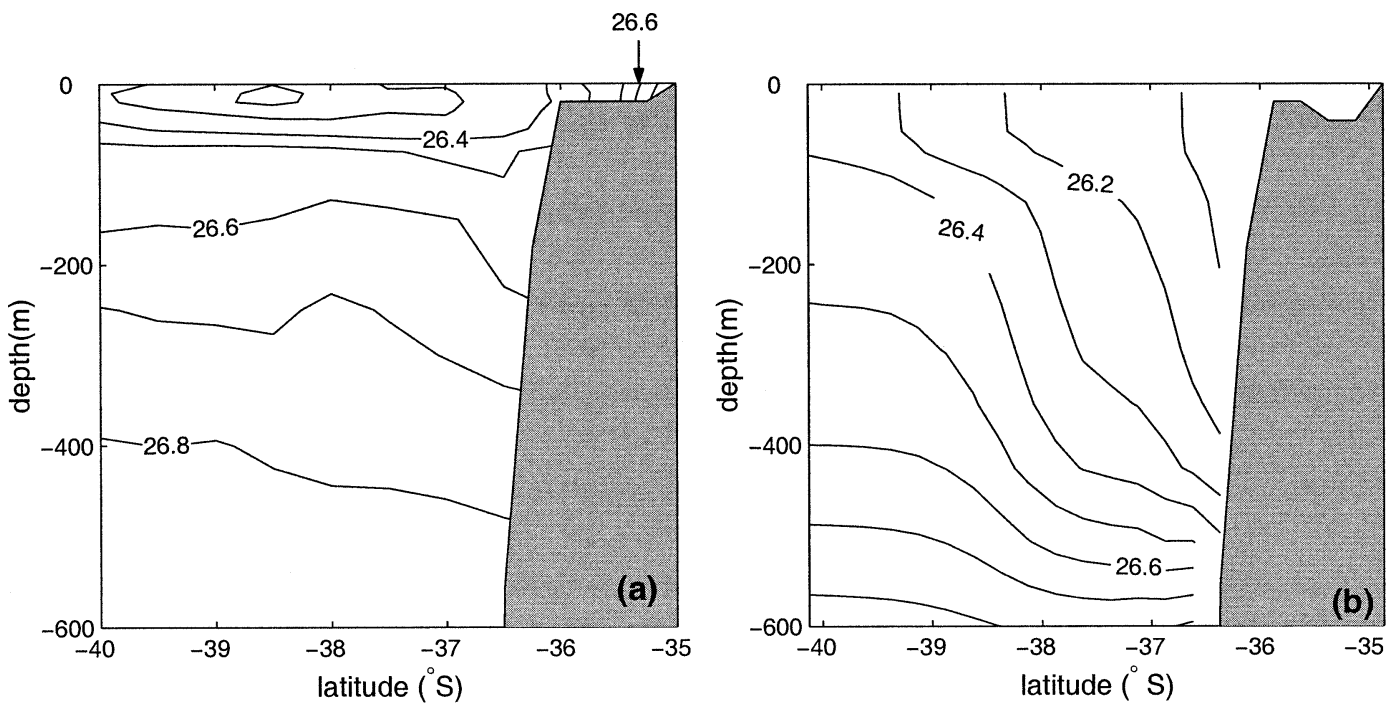

FIG. 3. A meridional transect $\left(136^{\circ} \mathrm{E}\right)$ of the density field for wintertime averages based on the (a) CARS $\left(\sigma_{t}\right)$ and (b) OCCAM $\left(\sigma_{\theta}\right)$ datasets. The interval is $0.1 \mathrm{~kg} \mathrm{~m}^{-3}$. Over the 600-m depths shown, the differences in $\sigma_{t}$ and $\sigma_{\theta}$ are less than $2 \%$. 


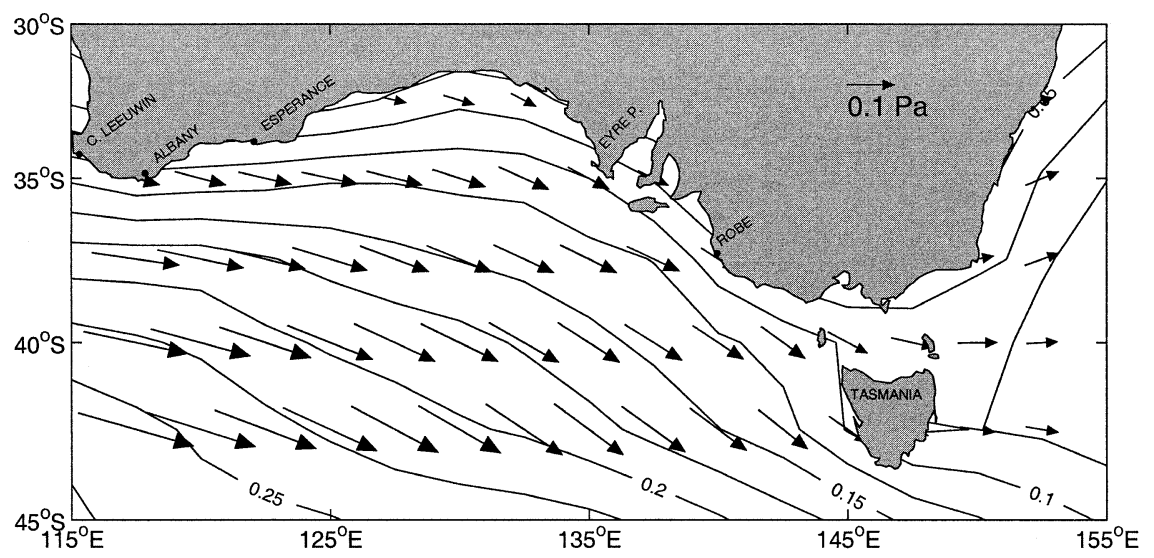

FIG. 4. Monthly averaged wind stress field for Aug based on ECMWF from Trenberth et al. (1989) climatology. Contour lines represent the magnitude of the wind stress in intervals of 0.025 $\mathrm{Pa}$. A vector of magnitude $0.1 \mathrm{~Pa}$ is indicated.

Interpolation errors can arise in POM from the estimation of the horizontal component of the buoyancy gradient $\mathrm{BG}_{\sigma}$ in the $\sigma$ coordinate system. In essence, vertical density gradients can be aliased into horizontal gradients and the problem is exacerbated next to steep topography (e.g., Haney 1991; Chu and Fan 1997; Mellor et al. 1998; Song 1998). With BG the buoyancy gradient computed in the Cartesian system, the error in the $\sigma$ coordinate system may be defined by $\epsilon=\mathrm{BG}_{\sigma}$ - BG. Two strategies were adopted to minimize this error. First, to improve the vertical resolution, the ratio of the change in adjacent cell depths ( $r$ value), was restricted to be less than 0.2 as recommended by Mellor et al. (1994).

Second, a correction for the error is made. Mellor et al. (1994) assumed that the error $\epsilon$ would not change in time, calculated it once, and corrected the buoyancy gradient to be $\mathrm{BG}_{\sigma}(t)-\epsilon$. In our model the density field and buoyancy gradient change slowly until an equilibrium is reached at around 40 days (see below). The error $\epsilon(t)$ will also be a function of time. Here, using the method of Fortunato and Baptista (1996), we calculate the error $\epsilon\left(t_{n}\right)$ at 10-day intervals $t_{n}=n 10$ days where $n=0,1,2, \ldots$. The error estimate is then assumed to not change during each 10-day interval. The corrected buoyancy gradient is then given by $\mathrm{BG}_{\sigma}(t)-$ $\epsilon\left(t_{n}\right)$, where $t_{n}<t<t_{n+1}$. Our choice of 10-day corrections is a little ad hoc but at least recognizes that the error does change in time: a more frequent correction led to unacceptably long computational overhead.

\section{b. The boundary conditions}

For the depth-averaged velocities and sea level, the set of boundary conditions adopted were based on Flather (1988) and Palma and Matano (1998). For the normal component of the depth-averaged velocity $(V)$, the discrete form of the scheme, at the eastern boundary may be written as

$$
V_{B}^{n+1}=V_{0}+\frac{c_{0}}{H}\left(\eta_{B-1}^{n+1}-\eta_{0}\right),
$$

where $V_{0}$ and $\eta_{0}$ are the prescribed depth-averaged velocity and sea level interpolated from OCCAM wintertime output, $c_{0}=\sqrt{g H}, B$ is a boundary point number, and $n$ is the time step. Further details of the boundary conditions can be found in Middleton and Platov (2003).

Results for the basic experiment were obtained by forcing the model with August average wind stress data (Trenberth et al. 1989; Fig. 4). Heat and freshwater fluxes were not applied in this experiment, although a sensitivity study using them is made in section 4 . To avoid the generation of spurious inertial oscillations, the boundary forcings, wind field, and gradients of temperature and salinity were ramped in from zero over a period of about 5 inertial days. In addition, the results were averaged over 2 days prior to presentation.

Last, we note that no changes in the circulation were found by halving the time step. In addition, the results obtained below using a constant horizontal diffusivity $\left(100 \mathrm{~m}^{2} \mathrm{~s}^{-1}\right)$ were found to be almost identical to those obtained using a Smagorinsky formulation (Smagorinsky 1963).

\section{c. Model spinup and overview}

The spinup of coastal circulation of the nested model occurs over the first 20 days or so through the rapid propagation of Kelvin and CTWs. The spinup of the deep ocean Sverdrup transport occurs over a short barotropic time scale of about 10 days (Middleton and Cirano 2002). The baroclinic setup can take several years, although here it is largely set up through the adopted OCCAM density field. This field is averaged over four austral winters, and after eight years of model evolution.

For the basic case (no surface cooling), results were obtained over 86 days and show the slope and eddy fields to become quasi stationary after 36 days or so. 


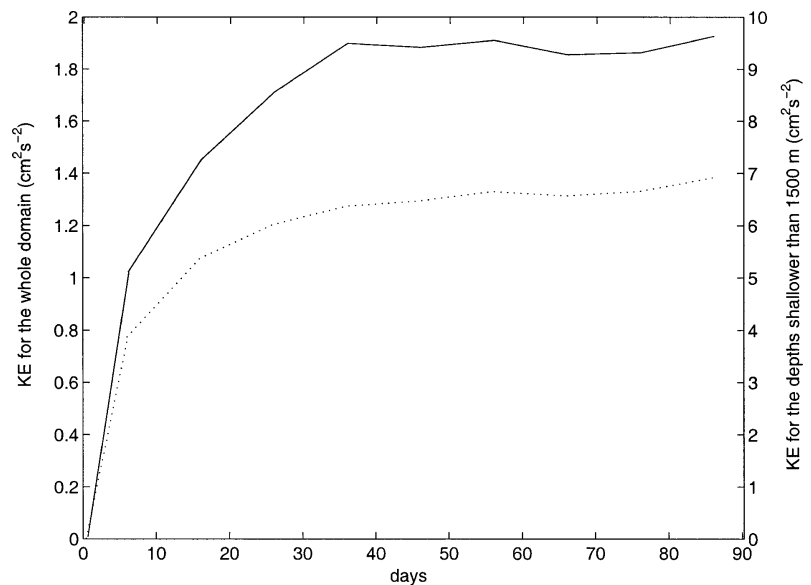

FIG. 5. The volume-averaged kinetic energy. The dotted line represents the total kinetic energy for the whole domain, and the scale is on the left. The solid line represents the kinetic energy calculated only for regions with depths shallower than $1500 \mathrm{~m}$ and adjacent to the coast. The scale is on the right.

Indeed, the volume-averaged kinetic energy of water shoreward of $1500 \mathrm{~m}$ (Fig. 5; solid curve) indicates only a slight increase after this time. There is a slight increase in the total kinetic energy after 36 days (Fig. 5, dotted curve).

As an overview of results for the entire region, consider the sea level field at day 56 shown in Fig. 6. A well-defined Leeuwin Current is found in the west and East Australian Current along the eastern Australian seaboard. In the eastern part of the domain (the focus of this study), the onshore Ekman transport leads to a rise in coastal sea level that changes little after day 26. The absolute value of coastal sea level is close to $50 \mathrm{~cm}$ for the gulfs and Robe region, while values of $26 \mathrm{~cm}$ are found in a similarly configured summertime model of the region (Middleton and Platov 2003). The seasonal change of $\sim 25 \mathrm{~cm}$ is broadly consistent with the 20 - $\mathrm{cm}$ seasonal variation estimated from coastal observations for the region (Pariwono et al. 1986).

A 400-km diameter cyclonic depression in sea level, here named the "Victorian low," is also found in the eastern domain. Evidence for this extensive feature (amplitude $5 \mathrm{~cm}$ ) is given in the June and July maps of sea level determined from altimeter and hydrographic data by Ridgway and Condie (2003, manuscript submitted to J. Geophys. Res.). The low is shown below to result from an anomalously dense patch of water that sits lower in the water column.

Over the shelf slope, a pattern of weak eddies is also apparent between the gulfs region and the west coast of Tasmania. These eddies are discussed in the appendix where it is shown that their locations are set by eddies found in the OCCAM density field. The eddies in OCCAM appear to be triggered by cross-shelf variations in the CC. However, aspects of the OCCAM shelf circulation are poorly modeled and for this reason, little more will be said about the eddy field.

\section{The South Australian region}

Details of the shelf and slope circulation are first presented and the former shown to be in good agreement with current meter observations. The relative importance of the Leeuwin Current, winds, and density field in driving the circulation is determined. A sensitivity study is then made to determine the role of dense water formation within Spencer Gulf and off Robe. Uncertainties in the surface fluxes and the relatively crude coastal topography adopted preclude a definitive study. Last, the transports of the $\mathrm{CC}$ and FC are determined.

\section{a. The coastal and Flinders currents}

Details of the horizontal circulation at day 56 and depths of 30 and $600 \mathrm{~m}$ are presented in Figs. 7 and 8 (as noted, the circulation changes little between days 36

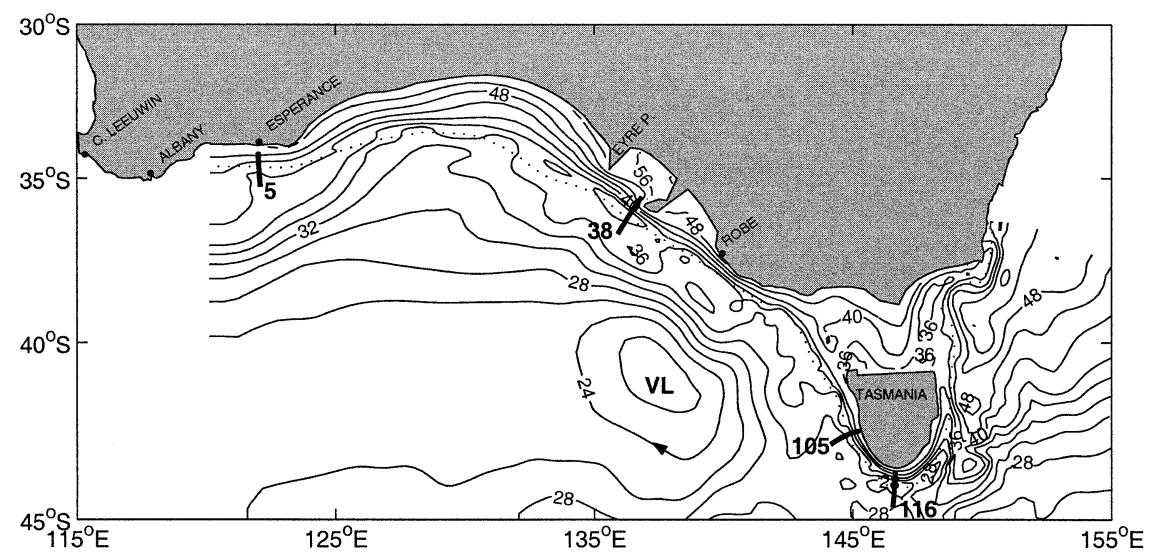

FIG. 6. The sea level field $\eta(\mathrm{cm})$ at day 56. Contour intervals of $2 \mathrm{~cm}$ for $\eta<36$ and $4 \mathrm{~cm}$ for $\eta \geq 36$. The dotted line represents the 1000 isobath. The circulation of the Victorian low (VL) is indicated by the arrow. The locations of several cross-shelf transects are also indicated. 


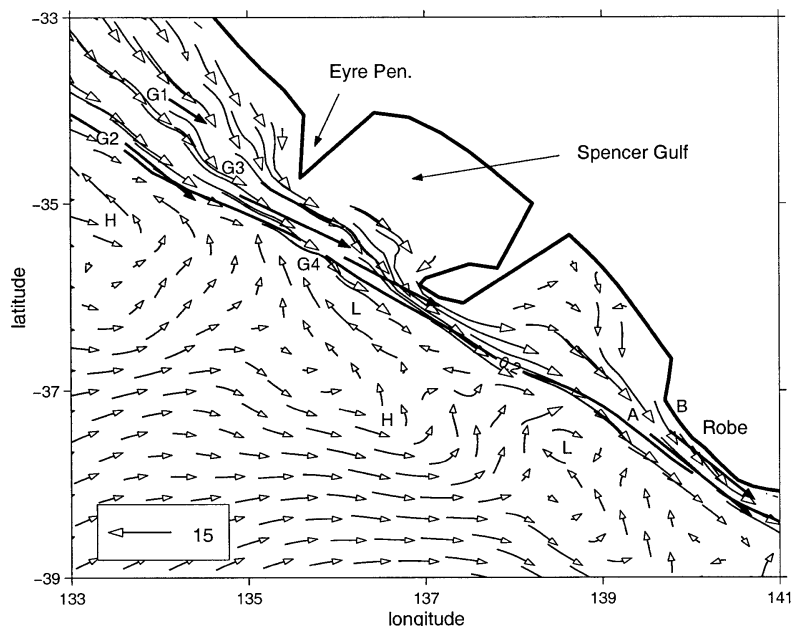

FIG. 7. The velocity field at a depth of $30 \mathrm{~m}$ and day 56 for the South Australian region. A vector of length $15 \mathrm{~cm} \mathrm{~s}^{-1}$ is indicated. The solid line denotes the $200-\mathrm{m}$ isobath. The solid arrows indicate the mean currents estimated from the current-meter data for the sites G1-G4 and A and B. The locations of several high (H) and low (L) pressure eddies are indicated.

and 86). Over the shelf, the 30-m-depth currents are to the southeast and maximal inshore of the shelf break $(200 \mathrm{~m})$. The current amplitudes peak at around $50 \mathrm{~cm}$ $\mathrm{s}^{-1}$ off the Eyre Peninsula, Kangaroo Island, and Robe where the shelf is narrowest. The weak eddy field farther offshore leads to a more complicated flow, but a surface component of the northwestward flowing FC is apparent.

At the 600-m depth, the amplitude of the FC is about $5-10 \mathrm{~cm} \mathrm{~s}^{-1}$ (Fig. 8) and is bounded in offshore extent by the 4000-m isobath. A cross-shelf transect of the current and density field to the immediate west of Kangaroo Island ( $J=38$ in Fig. 6) is illustrated in Fig. 9.

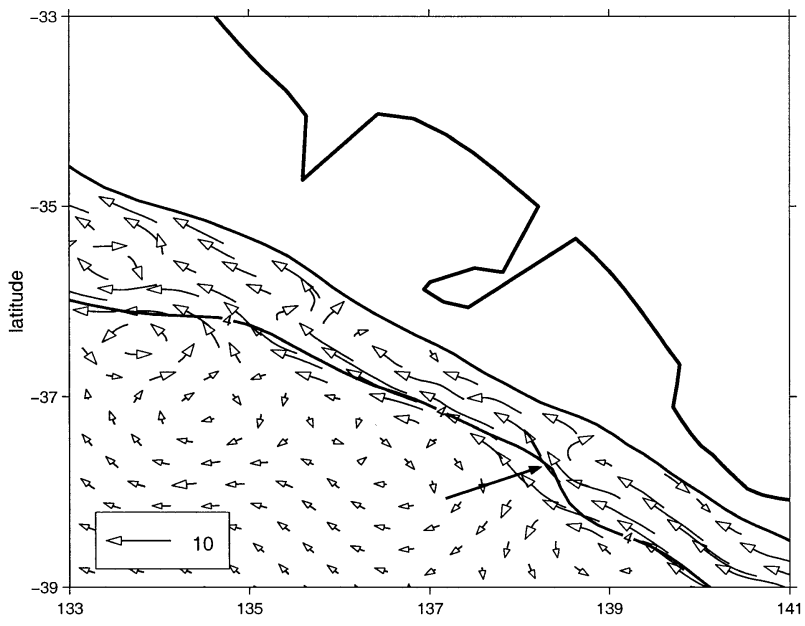

FIG. 8. The velocity field at a depth of $600 \mathrm{~m}$ and day 56 for the South Australian region. A vector of length $10 \mathrm{~cm} \mathrm{~s}^{-1}$ is indicated. The solid lines denote the 600- and 4000-m isobaths. The solid arrow indicates a region of abrupt change in the width of the slope.

At this cross section (and elsewhere), the water is well mixed in the top $150 \mathrm{~m}$. On the shelf, the alongshore current decreases with depth because of frictional effects. As shown in Fig. 7, the cross-shelf section here is directed along the axis of the offshore flow that is driven by the blocking effect of Kangaroo Island. At a depth of $200 \mathrm{~m}$, the cross-shelf and vertical (downwelling) velocities are of order $5 \mathrm{~cm} \mathrm{~s}^{-1}$ and $5 \mathrm{~mm} \mathrm{~s}^{-1}$ and lead to the evident downwelling of the isopycnals at this depth.

For water depths of 100-200 m, both model and observed alongshore currents change little with depth (Fig. 9; Table 1). The mean currents estimated from observations may thus be compared with the model results at the 30-m depth (Fig. 7). A more precise comparison
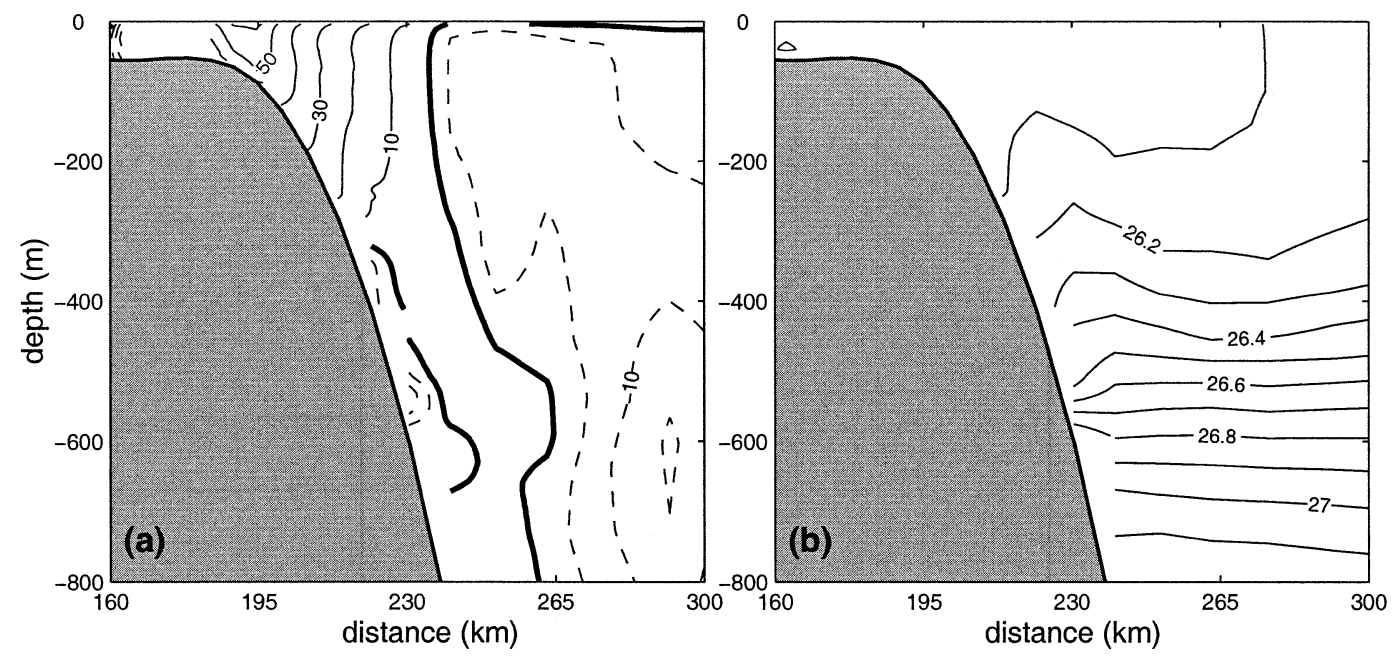

FIG. 9. Results for the Kangaroo Island transect $\left(J=38\right.$ in Fig. 6) at day 56. (a) Alongshore velocity: the contour intervals are $5 \mathrm{~cm} \mathrm{~s}^{-1}$ for negative velocities (north westward) and $10 \mathrm{~cm} \mathrm{~s}^{-1}$ for positive velocities (south eastward). The contour for zero velocity is represented by a thick line. (b) Density (interval $0.1 \mathrm{~kg} \mathrm{~m}^{-3}$ ). 
TABLE 1. Wintertime current-meter statistics obtained from available and published data. The First record and Days indicate the start time (dd: day, mm: month, yy: year - 1900) and number of days used to compute the statistics. The position of the instruments is in latitude $\left({ }^{\circ} \mathrm{S}\right)$ and longitude $\left({ }^{\circ} \mathrm{E}\right)$. The local depth and the depth of each instrument are also indicated. Results are presented for the mean component $(U, V)$ and its standard deviation $\left(\sigma_{u}, \sigma_{v}\right)$ in the east and north directions, respectively. Where the principal axis has been computed, results are presented for the major and minor directions. These are determined from the low-pass filtered data and the major axis is determined to be that with the largest standard deviation with the angle determined to lie in the direction of the mean current for that axis. The $y$ axis is taken to be the principal axis and the angle $\left(\theta_{p}\right)$ is in degrees anticlockwise of east. The magnitude of the vector mean $|\mathbf{U}|$ is given along with its direction $(\theta)$ in degrees anticlockwise from east. These statistics may be compared with the model results that are presented in the last two columns. Units for velocity are centimeters per second.

\begin{tabular}{|c|c|c|c|c|c|c|c|c|c|c|c|c|c|c|c|c|c|}
\hline \multicolumn{3}{|c|}{ Site } & \multirow{2}{*}{$\begin{array}{l}\text { First record } \\
(\mathrm{dd} / \mathrm{mm} / \mathrm{yy})\end{array}$} & \multirow[t]{2}{*}{ Days } & \multicolumn{2}{|c|}{ Position } & \multicolumn{2}{|c|}{ Depth $(\mathrm{m})$} & \multirow[t]{2}{*}{$U$} & \multirow[t]{2}{*}{$\sigma_{u}$} & \multirow[t]{2}{*}{$V$} & \multirow[t]{2}{*}{$\sigma_{v}$} & \multirow[t]{2}{*}{$\theta_{p}$} & \multirow[t]{2}{*}{$|\mathbf{U}|$} & \multirow[t]{2}{*}{$\theta$} & \multirow[t]{2}{*}{$|\mathrm{U}|_{\mathrm{pom}}$} & \multirow[t]{2}{*}{$\theta_{\text {pom }}$} \\
\hline & & & & & Lat $\left({ }^{\circ} \mathrm{S}\right)$ & Lon $\left({ }^{\circ} \mathrm{E}\right)$ & Local & Instr. & & & & & & & & & \\
\hline \multirow{3}{*}{ G1 } & Inner & $\mathrm{U}$ & $26 / 04 / 80$ & 40 & $34^{\circ} 00^{\prime}$ & $134^{\circ} 00^{\prime}$ & 100 & 30 & 6.4 & n.a. & -4.0 & n.a. & - & 7.6 & -32 & 14.5 & -18 \\
\hline & & $\mathrm{L}$ & & & & & & 80 & 5.1 & n.a. & -4.1 & n.a. & - & 6.5 & -39 & 16.0 & -56 \\
\hline & X-ray & & $08 / 04 / 81$ & 69 & $34^{\circ} 08^{\prime}$ & $133^{\circ} 57^{\prime}$ & 85 & 65 & 2.8 & n.a. & -5.1 & n.a. & - & 5.8 & -61 & 18.1 & -48 \\
\hline \multirow{4}{*}{ G2 } & \multirow[t]{2}{*}{ P\&L } & $\mathrm{U}$ & \multirow[t]{2}{*}{$26 / 04 / 80$} & \multirow[t]{2}{*}{40} & \multirow{4}{*}{$34^{\circ} 39^{\prime}$} & \multirow{4}{*}{$133^{\circ} 12^{\prime}$} & \multirow[t]{2}{*}{140} & $\overline{42}$ & 14.8 & n.a. & $\overline{-12.0}$ & n.a. & $=$ & 19.0 & $\overline{-39}$ & 16.9 & $\overline{-43}$ \\
\hline & & $\mathrm{L}$ & & & & & & 112 & 10.2 & n.a. & -12.1 & n.a. & - & 15.8 & -50 & 18.0 & -53 \\
\hline & Yankee & $\bar{U}$ & \multirow[t]{2}{*}{$08 / 04 / 81$} & 69 & & & 138 & 45 & 16.7 & n.a. & -14.0 & n.a. & - & 21.8 & -40 & 16.8 & -43 \\
\hline & & $\mathrm{L}$ & & & & & & 117 & 14.1 & n.a. & -11.8 & n.a. & - & 18.4 & -40 & 17.3 & -54 \\
\hline G3 & Whisky & $\overline{\mathrm{U}}$ & $07 / 04 / 81$ & 73 & $35^{\circ} 08^{\prime}$ & $134^{\circ} 22^{\prime}$ & 145 & 45 & 28.9 & n.a. & -10.5 & n.a. & $=$ & 30.8 & -20 & 24.0 & -22 \\
\hline & Victor & $\mathrm{U}$ & $06 / 04 / 81$ & 78 & & & 137 & 42 & 17.5 & n.a. & -10.1 & n.a. & - & 20.2 & -30 & 32.5 & -61 \\
\hline & & $\mathrm{L}$ & & & & & & 115 & 11.3 & n.a. & -15.5 & n.a. & - & 19.2 & -54 & 34.8 & -60 \\
\hline G4 & Gamma & $\mathrm{L}$ & $01 / 06 / 82$ & 81 & $35^{\circ} 46^{\prime}$ & $135^{\circ} 45^{\prime}$ & 142 & 122 & 8.6 & n.a. & -8.3 & n.a. & - & 11.9 & -44 & 34.5 & -60 \\
\hline & Delta & $\bar{U}$ & $26 / 08 / 82$ & 97 & & & 144 & 31 & -0.4 & n.a. & -1.3 & n.a. & - & 1.4 & -108 & 32.4 & -60 \\
\hline & & $\mathrm{L}$ & & & & & & 124 & 2.5 & n.a. & -3.9 & n.a. & - & 4.6 & -57 & 34.5 & -60 \\
\hline 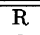 & A 82 & $\bar{U}$ & $08 / 08 / 82$ & 59 & $37^{\circ} 32^{\prime}$ & $139^{\circ} 31^{\prime}$ & 143 & 19 & 2.2 & 8.6 & 0.4 & 23.4 & -54 & 2.2 & -134 & 31.0 & -40 \\
\hline $\mathrm{O}$ & & $\mathrm{L}$ & & & & & & 111 & 0.6 & 4.4 & 7.4 & 22.2 & -54 & 7.4 & -60 & 38.0 & -49 \\
\hline B & A 83 & $\mathrm{~L}$ & $07 / 07 / 83$ & 57 & $37^{\circ} 32^{\prime}$ & $139^{\circ} 31^{\prime}$ & 143 & 112 & -2.7 & 5.0 & 28.3 & 24.6 & -54 & 28.5 & -49 & 38.0 & -49 \\
\hline $\mathrm{E}$ & B 83 & & $07 / 07 / 83$ & 57 & $37^{\circ} 26^{\prime}$ & $139^{\circ} 43^{\prime}$ & 50 & 24 & -2.0 & 4.0 & 25.8 & 25.7 & -54 & 25.9 & -50 & 28.5 & -39 \\
\hline & 10 & & $\begin{array}{l}18 / 04 / 84 \\
\end{array}$ & 70 & $39^{\circ} 02^{\prime}$ & $143^{\circ} 38^{\prime}$ & 89 & 76 & & & 4.3 & 7.8 & 2 & 4.3 & 2 & 5.9 & -20 \\
\hline B & 8 & & $18 / 04 / 84$ & 70 & $39^{\circ} 24^{\prime}$ & $143^{\circ} 51^{\prime}$ & 97 & 84 & & & 2.7 & 5.2 & -7 & 2.7 & -7 & 3.1 & -43 \\
\hline $\mathrm{S}$ & 7 & & $18 / 04 / 84$ & 70 & $40^{\circ} 12^{\prime}$ & $144^{\circ} 11^{\prime}$ & 60 & 47 & & & 11.2 & 10.2 & 62 & 11.2 & 62 & 7.4 & 80 \\
\hline & 1 & & $15 / 04 / 91$ & 96 & $40^{\circ} 50^{\prime}$ & $144^{\circ} 08^{\prime}$ & 95 & 65 & -3.3 & 3.3 & 2.1 & 6.3 & -75 & 4.0 & -17 & 5.7 & -49 \\
\hline $\mathrm{T}$ & S118-1 & & $01 / 07 / 88$ & 90 & $42^{\circ} 39^{\prime}$ & 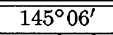 & 993 & 772 & 0.4 & 2.3 & 4.0 & 8.6 & -67 & 4.0 & -72 & 17.7 & -68 \\
\hline $\mathrm{A}$ & $\mathrm{R} 1$ & & $01 / 07 / 97$ & 90 & $42^{\circ} 26^{\prime}$ & $145^{\circ} 01^{\prime}$ & 100 & $40-90$ & 0.5 & 3.4 & 2.0 & 11.3 & -83 & 2.1 & -97 & & \\
\hline $\mathrm{s}$ & S117-1 & $\mathrm{U}$ & $01 / 07 / 88$ & 90 & $42^{\circ} 45^{\prime}$ & $144^{\circ} 55^{\prime}$ & 200 & 125 & -0.9 & 3.3 & 29.0 & 17.1 & -85 & 29.0 & -83 & 18.9 & -68 \\
\hline M & S117-2 & $\mathrm{L}$ & & & & & & 190 & -1.8 & 3.8 & 26.4 & 12.6 & -84 & 26.4 & -80 & 16.7 & -68 \\
\hline A & $\mathrm{R} 2$ & & $01 / 07 / 97$ & 90 & $42^{\circ} 33^{\prime}$ & $144^{\circ} 54^{\prime}$ & 188 & $80-180$ & 0.0 & 2.4 & 10.0 & 10.8 & -89 & 10.0 & -89 & & \\
\hline $\mathrm{N}$ & S116-2 & $\mathrm{M}$ & $01 / 07 / 88$ & 90 & $42^{\circ} 48^{\prime}$ & $144^{\circ} 51^{\prime}$ & 1000 & 323 & 0.1 & 4.5 & 3.9 & 12.3 & -70 & 3.9 & -69 & 3.9 & -136 \\
\hline I & S115-1 & $\mathrm{U}$ & & & & & & 167 & 7.1 & 12.8 & 1.7 & 14.8 & 22 & 7.3 & -54 & 3.0 & -72 \\
\hline A & S115-2 & $\bar{M}$ & $01 / 07 / 88$ & 90 & $42^{\circ} 57^{\prime}$ & $144^{\circ} 45^{\prime}$ & 2040 & 320 & -3.7 & 9.5 & 3.8 & 12.8 & -63 & 5.3 & -18 & 0.5 & -60 \\
\hline & S115-3 & $\mathrm{L}$ & & & & & & 995 & -2.1 & 4.7 & -3.1 & 9.3 & -39 & 3.7 & 107 & 4.6 & 101 \\
\hline
\end{tabular}

is made in Table 1 where the details of the current-meter deployments are also given (Provis and Lennon 1981; Hahn 1986; Schahinger 1987). Where mean currents are available at more than one depth an average is presented in Fig. 7. It should be noted that the mooring sites shown in Fig. 7 and used in the Table 1 are approximate since the topography has been smoothed to minimize twogridpoint instabilities.

Beginning with the westernmost site, the midshelf means at G1 indicate a southeastward flow of about 7 $\mathrm{cm} \mathrm{s}^{-1}$. The direction is similar to the model flow but the amplitude smaller than the model speed of $16 \mathrm{~cm}$ $\mathrm{s}^{-1}$ (Fig. 7; Table 1). The data farther offshore (G2) indicate that the $\mathrm{CC}$ is intensified nearer to the shelf break with velocities of order $18 \mathrm{~cm} \mathrm{~s}^{-1}$ that are directed to the southeast and along isobaths $\left(-40^{\circ}\right.$ anticlockwise from east). The model results are in good agreement with these data.

For G3, the shelfbreak site off the Eyre Peninsula, the data indicate flow to the southeast with mean speed of $31 \mathrm{~cm} \mathrm{~s}^{-1}$. The model current direction is almost identical but the magnitude is somewhat smaller $(24 \mathrm{~cm}$ $\left.\mathrm{s}^{-1}\right)$.

For G4, a shelfbreak site off the mouth of Spencer
Gulf, the data indicate mean speeds of $12-20 \mathrm{~cm} \mathrm{~s}^{-1}$ that are smaller than in the model $\left(\sim 33 \mathrm{~cm} \mathrm{~s}^{-1}\right)$ but again in a similar direction. An exception here is the data obtained in late 1982 (Delta), which indicate mean speeds of only 1.4 and $4.6 \mathrm{~cm} \mathrm{~s}^{-1}$. The possible cause of these weaker currents here is the drop in sea level associated with the 1982-83 El Ninõ. Pariwono et al. (1986) have shown that, between August 1982 and March 1983, coastal sea level for this region is 5-10 $\mathrm{cm}$ lower than the long-term mean. Such a drop in sea level may well be related to the lowering of sea level in the west Pacific and subsequent propagation along Australia's shelves (Clarke and Van Gorder 1994).

Off Robe, the standard deviations for the major component axis are of order of $23 \mathrm{~cm} \mathrm{~s}^{-1}$ and are comparable to or greater than the mean currents (Table 1). Such variability is expected because of the strong CTWs, which are known to dominate the subinertial circulation (Schahinger 1987; Middleton and Black 1994). Of particular interest here is the large increase in the mean alongshore currents between the winters of 1982 and 1983: the former an El Ninõ year. During 1982, the mean current near the shelf break was about $2 \mathrm{~cm} \mathrm{~s}^{-1}$, directed offshore near the surface (A82U) and to the 


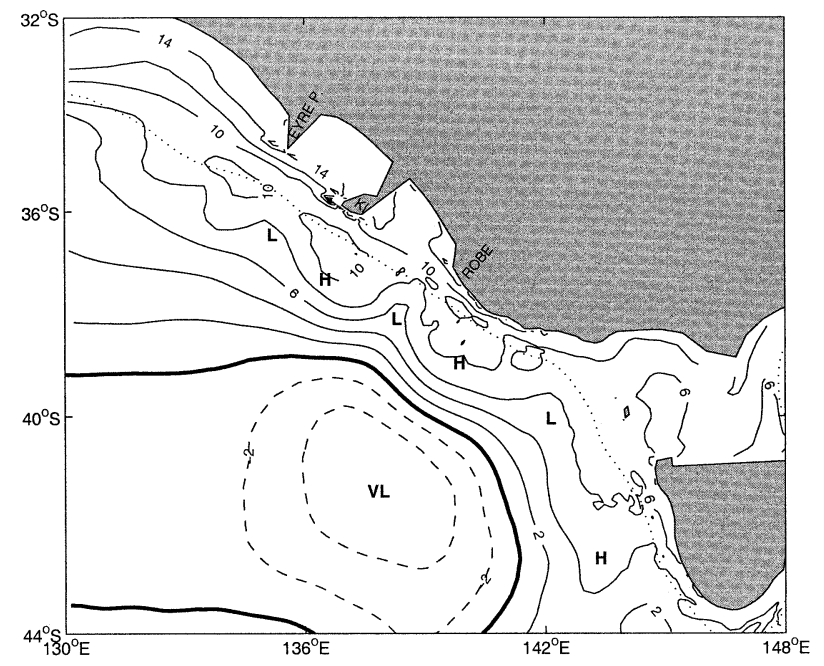

FIG. 10. Sea level at day 10 for the adjustment solutions in which the wind and boundary forcing are set to zero. The contour interval is $2 \mathrm{~cm}$, and the zero contour is represented by a thick line. The dotted line is the 1000-m isobath. The locations of several high $(\mathrm{H})$ and low (L) pressure eddies are indicated.

southeast (alongshore) closer to the bottom (A82L). During 1983, the near-bottom mean (A83L) was again directed to the southeast but with a much larger mean of $29 \mathrm{~cm} \mathrm{~s}^{-1}$. The mean obtained over the shelf during that year (B83) was also large $\left(26 \mathrm{~cm} \mathrm{~s}^{-1}\right)$ and directed to the southeast. The model results at Robe compare favorably with the 1983 winter mean results (post El Niño) at both the shelf site (B) and shelfbreak site (A) (see Fig. 7 and Table 1).

\section{b. Adjustment to the density field alone}

The role of the initial density field adopted may be determined by setting the surface wind stress to zero. In addition, the boundary forcing is also set to zero with $V_{0}=\eta_{0}=0$ in the Flather condition described in Eq. (1). The sea level and velocity field then adjust (from a state of zero) to the pressure gradients associated with the density field and light (dense) water sits higher (lower) in the water column (Middleton 2000; Middleton and Platov 2003).

The results for sea level at day 10 are shown in Fig. 10. Denser water lies farther to the south and southeast along with a light water wedge adjacent to the shelf break that results from downwelling (e.g., Fig. 3). In response, sea level sits higher over the shelf and lower to the south and southeast (Fig. 10). The pattern of sea level is very similar to that in the basic case (Fig. 11) and generally has reached a quasi-steady state by day 10. Weak eddies are found at similar locations along the shelf slope and continue to evolve indicating the presence of baroclinic instability. Farther south, a large scale "Victorian low" is also found in both cases and results from a local pool of anomalously dense water at depths

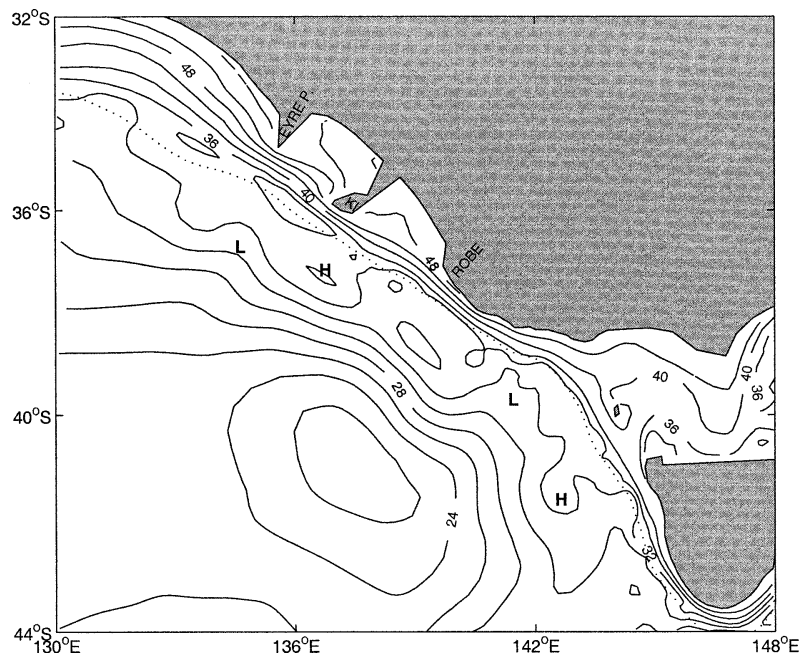

FIG. 11. The sea level field at day 56 for the basic case in which the wind and boundary forcing are nonzero. Contour intervals are 2 $\mathrm{cm}$ for $\eta<36 \mathrm{~cm}$ and $4 \mathrm{~cm}$ for $\eta \geq 36 \mathrm{~cm}$. The dotted line indicates the 1000-m isobath. The locations of several high $(\mathrm{H})$ and low $(\mathrm{L})$ pressure eddies are indicated.

of 200-500 m: the denser water sits lower in the water column.

Over the shelf, the sea level gradient in the basic case is larger than for the adjustment solutions due to the onshore Ekman transport by the zonal winds. The CC associated with the adjustment solutions is illustrated by the Kangaroo Island cross section shown in Fig. 12. The shelf currents here (and elsewhere) are up to one half of those in the basic case (Fig. 9). An FC is also found that is typically $2-3 \mathrm{~cm} \mathrm{~s}^{-1}$ or one-third of that found in the basic case.

\section{c. The importance of the Leeuwin Current and winds}

The alongshore velocity field of the Leeuwin Current off Esperance is illustrated in Fig. 13a. A maximum current of $20 \mathrm{~cm} \mathrm{~s}^{-1}$ is found and is much smaller than the $80 \mathrm{~cm} \mathrm{~s}^{-1}$ found in ADCP observations off Albany (Cresswell and Peterson 1993). Admittedly, the shelf off Albany is narrower, but the discrepancy raises the question of the extent and importance of the Leeuwin Current in driving the shelf circulation.

To answer this, the model was run both with and without wind forcing and, in both cases, with density gradients set to zero: two "barotropic experiments." These results were run out to a steady state and will be compared with the basic-case results. The role of the density gradients will again be evaluated.

The alongshore velocity off the Eyre Peninsula and for the two barotropic experiments is presented in Fig. 13b. For these experiments the velocities driven by the Leeuwin Current alone (boundary forcing, no wind) are less than $7 \mathrm{~cm} \mathrm{~s}^{-1}$ and about one-third of those driven by both winds and the Leeuwin Current $\left(<25 \mathrm{~cm} \mathrm{~s}^{-1}\right)$. The depth-averaged alongshore currents from the basic 


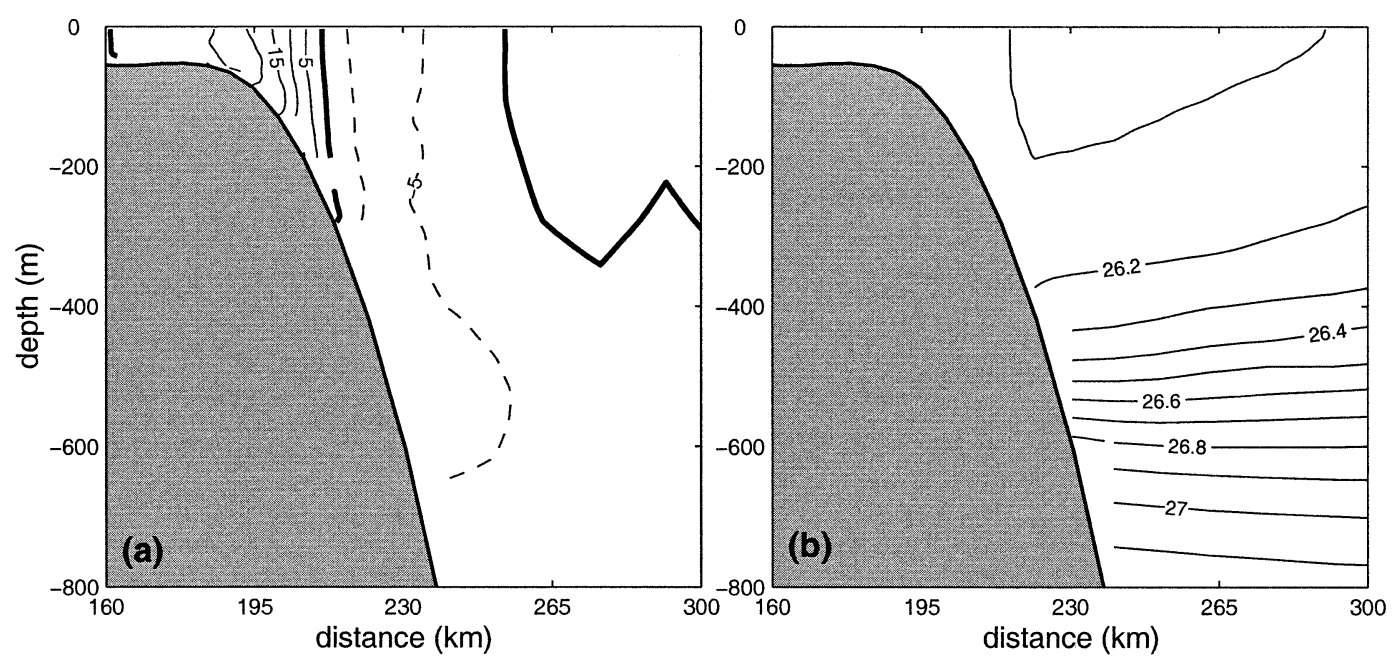

FIG. 12. Adjustment results for the Kangaroo Island transect $(J=38$ in Fig. 6$)$ at day 10. (a) Alongshore velocity: the contour interval is $5 \mathrm{~cm} \mathrm{~s}^{-1}$ and the contour for zero velocity is represented by a thick line. Positive (negative) velocities are southeastward (northwestward). (b) Density (interval $0.1 \mathrm{~kg} \mathrm{~m}^{-3}$ ).

case (where density gradients also exist) are also presented and are larger still $\left(<45 \mathrm{~cm} \mathrm{~s}^{-1}\right)$. The stronger currents here result from the additional forcing by the density field that was noted above. Indeed, as a percentage, the Leeuwin Current, winds and density field drive about $18 \%, 47 \%$, and $35 \%$ of the $1.9 \mathrm{~Sv}(\mathrm{~Sv} \equiv$ $10^{6} \mathrm{~m}^{3} \mathrm{~s}^{-1}$ ) transport between the coast and the 200-m isobath. We conclude that the Leeuwin Current has little effect on shelf currents to the east of the Eyre Peninsula.

\section{d. Dense water formation: Surface cooling}

As a sensitivity study, the regional model was also forced with surface fluxes of heat (Josey et al. 1996) and freshwater (da Silva et al. 1994). The net cooling for the winter period is largest near the coast (about 60 $\mathrm{W} \mathrm{m}^{-2}$ ). The freshwater fluxes are somewhat unreliable since, unrealistically, evaporation is not found to exceed precipitation for the Spencer Gulf region (e.g., NunesVaz et al. 1990). The production of dense water is, however, dominated by the heat fluxes, which are in better agreement with other studies (e.g., Herzfeld 1997). The application of these fluxes was also found to lead to the development of an unrealistically deep surface mixed layer. In light of these uncertainties, results are only presented to illustrate the possible effects of dense water formation on the circulation.

In qualitative agreement with CARS data (e.g., Fig.
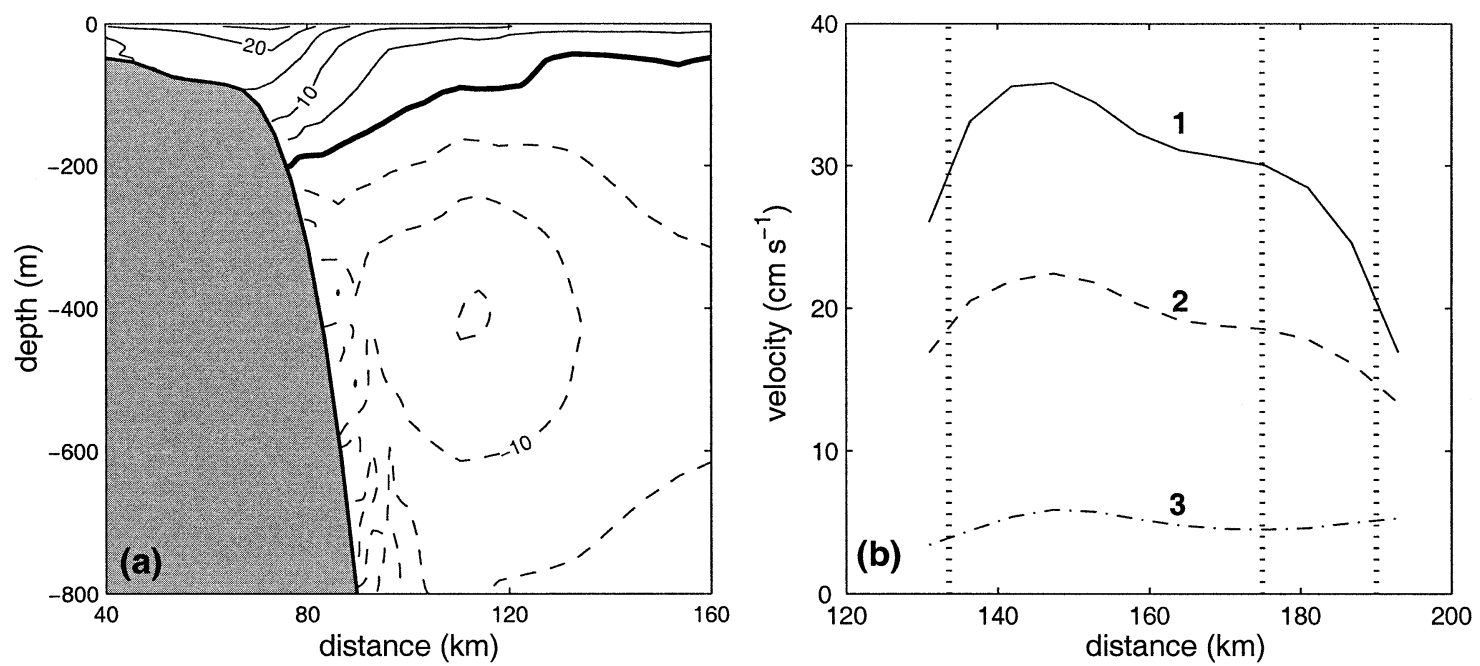

FIG. 13. (a) Alongshore velocity for the Esperance transect ( $J=5$ in Fig. 6$)$ at day 56 . The contour interval is $5 \mathrm{~cm} \mathrm{~s}^{-1}$, and the contour for zero velocity is represented by a thick line. (b) The depth-averaged velocity for the Eyre Peninsula transect $(J=32)$ obtained from 1$)$ the basic case results, 2) barotropic results with wind forcing, and 3) barotropic results without wind forcing. All results are for day 56. From left to right, the vertical dashed lines indicate the locations of the 50-, 100-, and 200-m isobaths. 

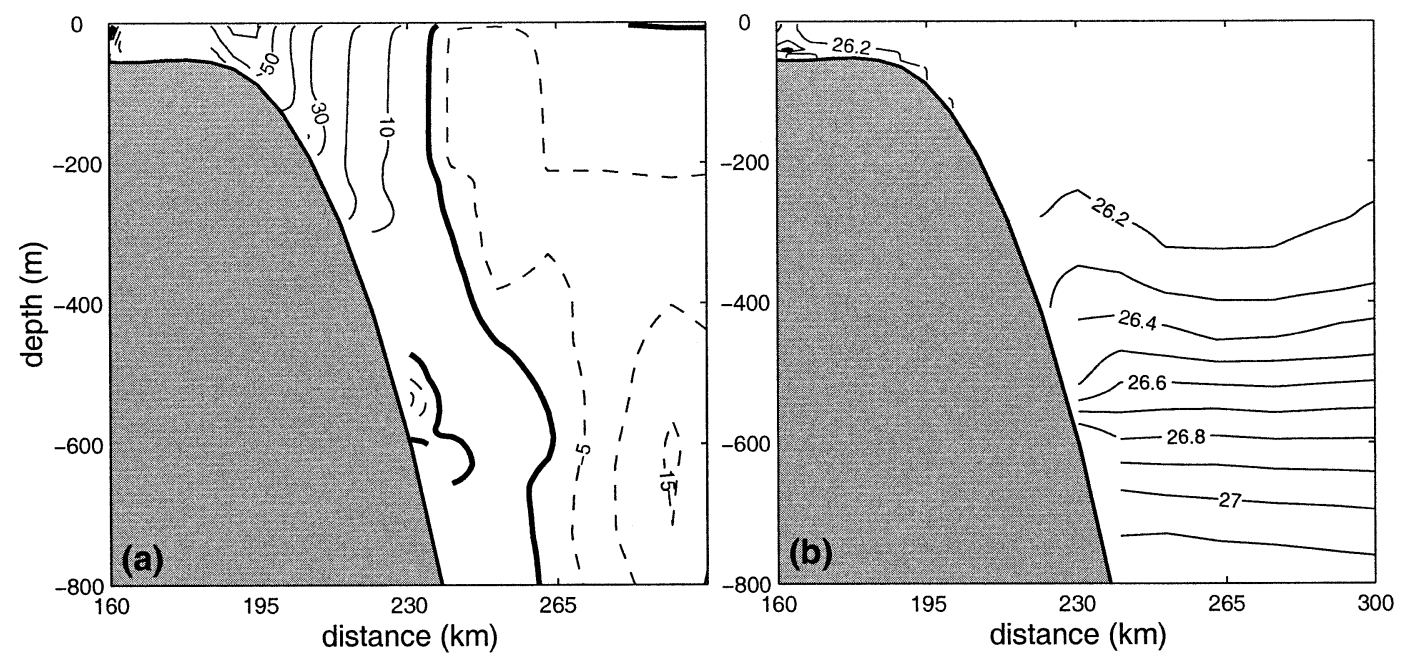

FIG. 14. As in Fig. 9 but for the case in which surface fluxes of heat and freshwater are applied.

3a), relatively dense water is formed along the coast of the bight and notably within Spencer Gulf and the Coorong. Cross-shelf results for the Kangaroo Island transect are shown in Fig. 14. Through geostrophy, the denser water formed near the coast acts to enhance the CC by up to $5 \mathrm{~cm} \mathrm{~s}^{-1}$ over that obtained in the basic case (Fig. 9a). The pattern of horizontal circulation and sea level field is otherwise very similar to that shown above (Figs. 7, 8, and 11).

The cross-shelf flow is enhanced notably off Kangaroo Island and Robe. For Kangaroo Island the effects are shown in Fig. 14b, where dense water cascades to depths of $250 \mathrm{~m}$ or more. The extent and depth of the cascade is very similar to that observed in hydrographic data by Godfrey et al. (1986). The cross-shelf and vertical velocities at a depth of $200 \mathrm{~m}$ are about 3 times that found in the absence of surface cooling and of order $15 \mathrm{~cm} \mathrm{~s}^{-1}$ and $15 \mathrm{~mm} \mathrm{~s}^{-1}$, respectively.

\section{e. Transports}

The depths of the CC and FC do vary somewhat throughout the domain. However, the results indicate that the $\mathrm{CC}$ and FC are largely confined to depths shoreward of the 500- and 4000-m isobaths, respectively. Since there is some variation, we adopt two definitions

TABLE 2. The transports of the coastal current (CC) and Flinders Current (FC) calculated at the transects indicated in Fig. 6. Values are in Sverdrups, and positive and negative values are to the east (poleward) and west (equatorward), respectively. The unbracketed and bracketed values are obtained using definitions 1 and 2 given in the text.

\begin{tabular}{lcccc}
\hline \hline & $J=5$ & $J=38$ & $J=105$ & $J=116$ \\
\hline CC & 0.7 & 2.4 & 0.8 & 1.4 \\
& $(0.9)$ & $(2.4)$ & $(0.8)$ & $(1.4)$ \\
FC & -6.7 & -4.4 & -4.0 & -12.7 \\
& $(-6.9)$ & $(-5.9)$ & $(-4.6)$ & $(-13.5)$ \\
\hline
\end{tabular}

of the transports. Definition 1: for the CC, the transport is defined to be of all water shoreward of the $500-\mathrm{m}$ isobath and for the FC, the transport is of all water bounded by the $500-$ and $4000-\mathrm{m}$ isobaths. Definition 2 : for the CC, the transport is of all water moving eastward (poleward) and shoreward of the 500-m isobath, while for the FC, the transport is of all water moving westward (equatorward) and shoreward of the 4000-m isobath. The latter definition allows for variations in the depths of the currents but is not strictly mass conserving.

Results were obtained for the four transects shown in Fig. 6 and are presented in Table 2. The transports obtained using the two definitions are very similar. Off Esperance $(J=5)$, the transports of the $\mathrm{CC}$ and $\mathrm{FC}$ are about 0.8 and $6.8 \mathrm{~Sv}$, respectively. The transport of the $\mathrm{CC}$ increases to $2.4 \mathrm{~Sv}$ off Kangaroo Island $(J=38)$ because of the alongshore winds. The transport of the FC decreases to a value between 4.4 and $5.9 \mathrm{~Sv}$ : average $5.2 \mathrm{~Sv}$. One reason for this is that the "fetch" over which the equatorward Sverdrup transport can contribute to the FC is reduced to the longitude range $136^{\circ}$ (Kangaroo Island) to $145^{\circ} \mathrm{E}$ (the southern tip of Tasmania).

The average reduction in the transport of the FC (1.6 Sv) may be compared with the equatorward Sverdrup transport between Kangaroo Island and Esperance. The latter, estimated from the curl of the wind stress and at a latitude of $39^{\circ} \mathrm{S}$, is $4.4 \mathrm{~Sv}$ and is larger than the change in the transport of the FC (1.6 Sv).

The reason for the discrepancy lies in the spatially nonuniform density and wind fields which lead to currents that oppose the FC. Indeed, using an idealized box model driven by a uniform wind stress curl, Middleton and Cirano (2002) showed that the equatorward Sverdrup transport did account for westward increases in the magnitude of an idealized FC. We do not find such a result here, and the likely reason lies with the spatial variability of the density field and winds. The ocean 


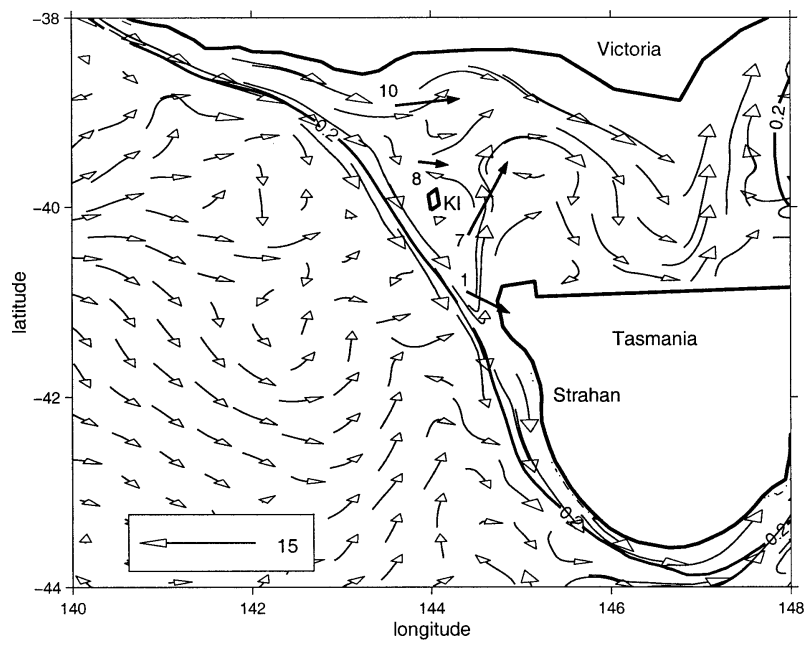

FIG. 15. The velocity field at a depth of $30 \mathrm{~m}$ and day 56 for the Bass Strait region. A vector of length $15 \mathrm{~cm} \mathrm{~s}^{-1}$ is indicated. The solid line denotes the $200-\mathrm{m}$ isobath. The solid arrows indicate the mean currents estimated from the current-meter data for the sites 10 , 8,7 , and 1 . King Island $(\mathrm{KI})$ is indicated.

model responds by setting up meridional sea level gradients (Fig. 6) and eastward currents that act to reduce the magnitude of the FC near the surface (Figs. 9 and 13). In the idealized model of Middleton and Cirano (2002), such gradients occur shoreward of the shelf break and vertical variations in the FC are largely confined to the bottom boundary layer.

\section{The Victoria-Tasmanian region}

The circulation for the Bass Strait region is examined first and simple models of CTW propagation and wind forcing used to explain the results. The shelf circulation is then examined and results again are found to compare well with limited observations. Estimates of the $\mathrm{CC}$ and FC transports are discussed.

\section{a. Bass Strait}

Within the 60-70-m-deep strait, the model (and actual) density field is well mixed in the vertical (Baines et al. 1991) and the 30-m-deep velocity field (Fig. 15) therefore largely follows the sea level contours shown in Fig. 6. Water moves to the east and then north as a current trapped to the southeastern coast of Victoria. Some of this outflow combines with the southward flowing East Australian Current that lies offshore of the $1000-\mathrm{m}$ isobath. Notably, water is drawn in to the strait as a jet near the northwest tip of Tasmania (Fig. 15). Estimates of the net model transport through the strait show that it is directed to the east equal to $0.95 \mathrm{~Sv}$ and is 2 times that estimated from current-meter observations for the region (Baines et al. 1991).

To explain the details of the circulation and forcing mechanisms, we consider two simple models for the circulation within the strait generated by zonal winds and the $\mathrm{CC}$, incident on the western mouth of the strait. These models have zero bottom drag and, while linear and idealized, will help to explain the transport through the strait and jet near the northwest tip of Tasmania.

Consider first the schematic of sea level and circulation (Fig. 16a) that is driven by a CC on the west Victorian shelf. The schematic is taken from Middleton and Viera (1991) and Middleton and Black (1994) and corresponds to the solution for the scattering of a lowfrequency mode-1 CTW by the western mouth of the strait. It also represents an approximate steady solution for the sea level that is set up by a CC incident on the western mouth of the strait (Middleton and Platov 2000) and the dynamics are the same.

Within the strait, the scattering results in the generation of Kelvin waves and Poincaré waves, the latter trapped to the mouths of the strait. On the adjacent shelves, CTWs are generated. Since these waves can only propagate with the coast on the left, the circulation is preferentially expelled from the strait along the eastern Victorian shelf. Such a result is found in the numerical model and is illustrated in part by Figs. 6 and 15.

Now, in the absence of friction, coastal sea level along southern Victoria will be equal to that of the CC $\left(\eta_{c}\right)$. For argument's sake, we take $\eta_{c}$ to be $10 \mathrm{~cm}$. On the east Tasmanian coast, sea level is also assumed to be constant with a value of $\eta_{0}=0 \mathrm{~cm}$. Now, since there can be no flow into the north Tasmanian coast $(f v=$ $g \eta_{x}=0$ ), sea level will be constant along that coast. The sea level difference $\eta_{c}-\eta_{0}$ will set the net geostrophic transport through the strait. Water must therefore be drawn into the strait and the sea level contours and circulation must "bend back" into the strait as illustrated in Fig. 16a. A jet is also found at its southwestern corner (see also Middleton and Black 1994). The jet arises from the first and second CTW modes generated at the western shelf. The modes are $180^{\circ}$ out of phase so that net coastal sea level at the northwestern tip of Tasmania will be equal to $\eta_{0}$ and zero as required. The velocity field of the mode- 2 wave is thus directed to the north and results in the jet.

The contribution by the $\mathrm{CC}$ to the transport through the strait can be estimated from

$$
U_{c}=-g H\left(\eta_{c}-\eta_{0}\right) / f
$$

where $H$ is the depth of the strait. From Fig. 6, we take $\eta_{c}=44 \mathrm{~cm}$ and $\eta_{0}=36 \mathrm{~cm}$ so that, with $f=-9 \times$ $10^{-5} \mathrm{~s}^{-1}$ and $H=60 \mathrm{~m}$, we get $U_{c}=0.53 \mathrm{~Sv}$, or just over one-half of that estimated from the model. In addition, the result also illustrates that the transport through the strait can be affected by sea level $\eta_{0}$ and currents on the west coast of Tasmania: Garrett and Toulany (1982) named this mechanism "geostrophic control."

An additional mechanism, which will act to draw water into the southwest corner of the strait, involves the 

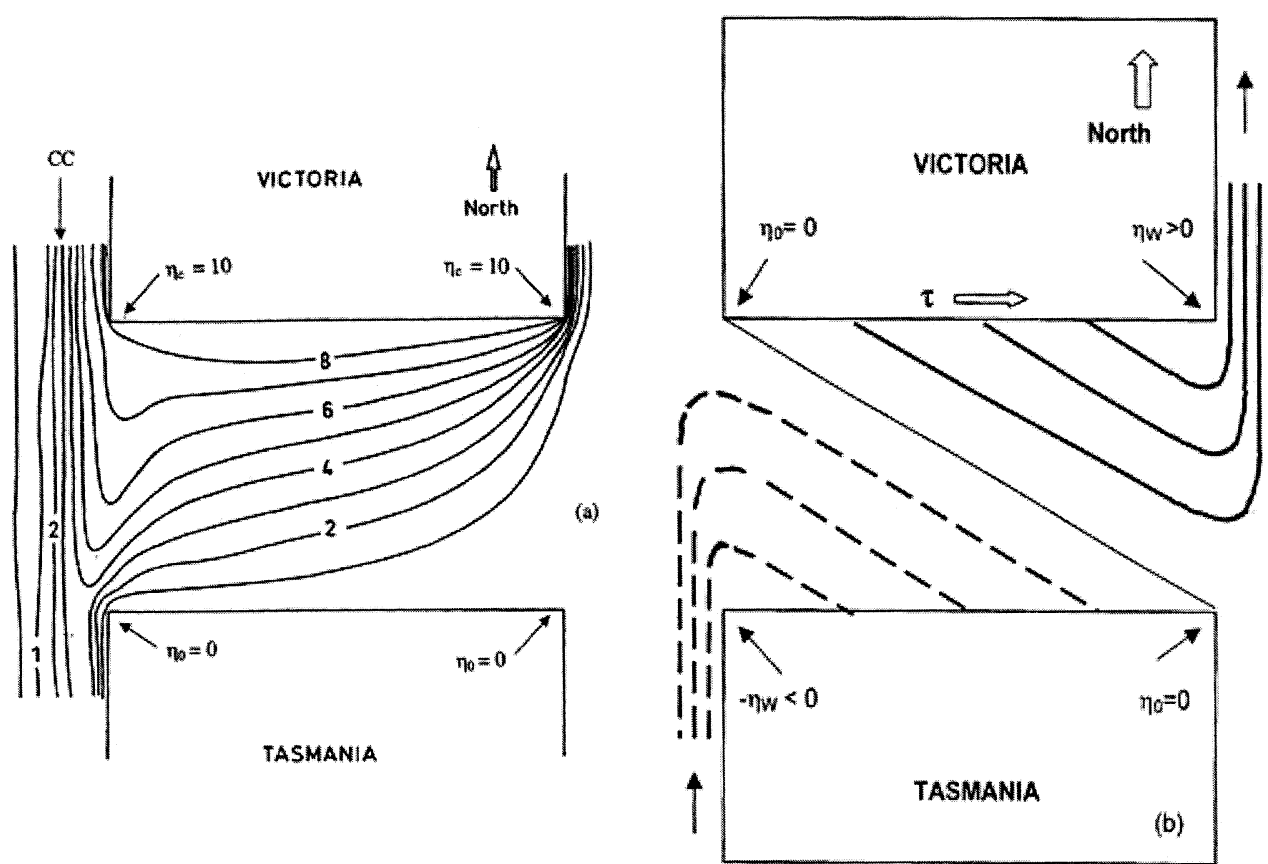

Fig. 16. (a) A schematic illustrating sea level set up by a coastal current incident on the western mouth of Bass Strait. Assuming a geostrophic balance, coastal sea level on the Victorian coast is equal to that of the coastal current $\left(\eta_{c}\right)$ and is assumed to be $10 \mathrm{~cm}$. On the northern Tasmanian coast, coastal sea level must be equal to that on the east Tasmanian coast $\left(\eta_{0}\right)$ and is assumed to be zero. (b) A schematic illustrating sea level set up within the strait by a zonal wind stress $(\tau)$. Sea level is raised (lowered) on the Victorian (Tasmanian) coast by the Ekman transport. The flow is preferentially drawn in and expelled along the west Tasmanian and east Victorian shelves (the arrows).

zonal wind stress $\tau$ within the strait. Following Middleton and Viera (1991), we consider barotropic motion without bottom drag in a zonally oriented rectangular strait as illustrated in Fig. 16b. The steady equations of motion are

$$
\begin{aligned}
-f v & =-g \frac{\partial \eta}{\partial x}+\frac{\tau}{\rho_{0} H} \text { and } \\
f u & =-g \frac{\partial \eta}{\partial y},
\end{aligned}
$$

where $x$ and $y$ are directed to the east and north. Now, since the CTW crests propagate with the coast on the left, the circulation within the strait cannot affect sea level on the west Victorian and east Tasmanian shelves. Moreover, since the northward Ekman transport $V_{E}$ is unimpeded here, it cannot lead to changes in sea level and $\eta_{0}=0$ (Fig. 16b).

Within the strait, the Ekman transport leads to a symmetric raising and lowering of coastal sea level along the Victorian and Tasmanian coastlines, as shown, with an amplitude $\eta_{w}>0$ at the northwest corner and $-\eta_{w}$ at the southeast corner. The solution for $\eta_{w}=\tau L /\left(\rho_{0} g H\right)$ is obtained from Eqs. (3) and (4) by noting that $v=0$ and the net transport due to wind forcing is

$$
U_{w}=-\tau L /\left(f \rho_{0}\right),
$$

where $L=400 \mathrm{~km}$ denotes the length of the strait. For the August climatology (Fig. 4), $\tau \approx 0.07 \mathrm{~Pa}$, and so the net transport is about $0.3 \mathrm{~Sv}$ or $30 \%$ of that found for the numerical model.

It should be noted that the above solution for coastal sea level and transport in Eq. (5) are unchanged by the presence of the adjacent shelves. However, within the strait the effect of the shelves does alter sea level. Since CTWs can only propagate with the coast on the left, the sea level contours at the eastern end of the strait must bend to the east and then north as shown in Fig. 16b. The opposite occurs on the western side of the strait and a wavelike pattern results that is similar to that obtained in the model (Fig. 11): part of this wave pattern will be driven by variations in the Victorian coastline.

In addition, the schematic Fig. 16b shows that a jet into the southwest corner of the strait will result and this will act in unison with that driven by the CC (Fig. 16a). Indeed, of the $0.95 \mathrm{~Sv}$ transport through the strait, a total of $0.43 \mathrm{~Sv}$ (or almost one-half) is driven between King Island and Tasmania.

The existence and magnitude of the eastward flow into the strait and northeastward jet near Tasmania is supported by current meter observations for the region (Baines et al. 1991), with results presented in Fig. 15 and Table 1. For the northernmost mooring, site 10, both the data and model indicate an eastward flow while the magnitude of the latter $\left(6 \mathrm{~cm} \mathrm{~s}^{-1}\right)$ is larger than that of the data $\left(4 \mathrm{~cm} \mathrm{~s}^{-1}\right)$. At site 8 , the observed and model currents are in approximate agreement and smaller than those at site 10. South of King Island (site 7), the model 

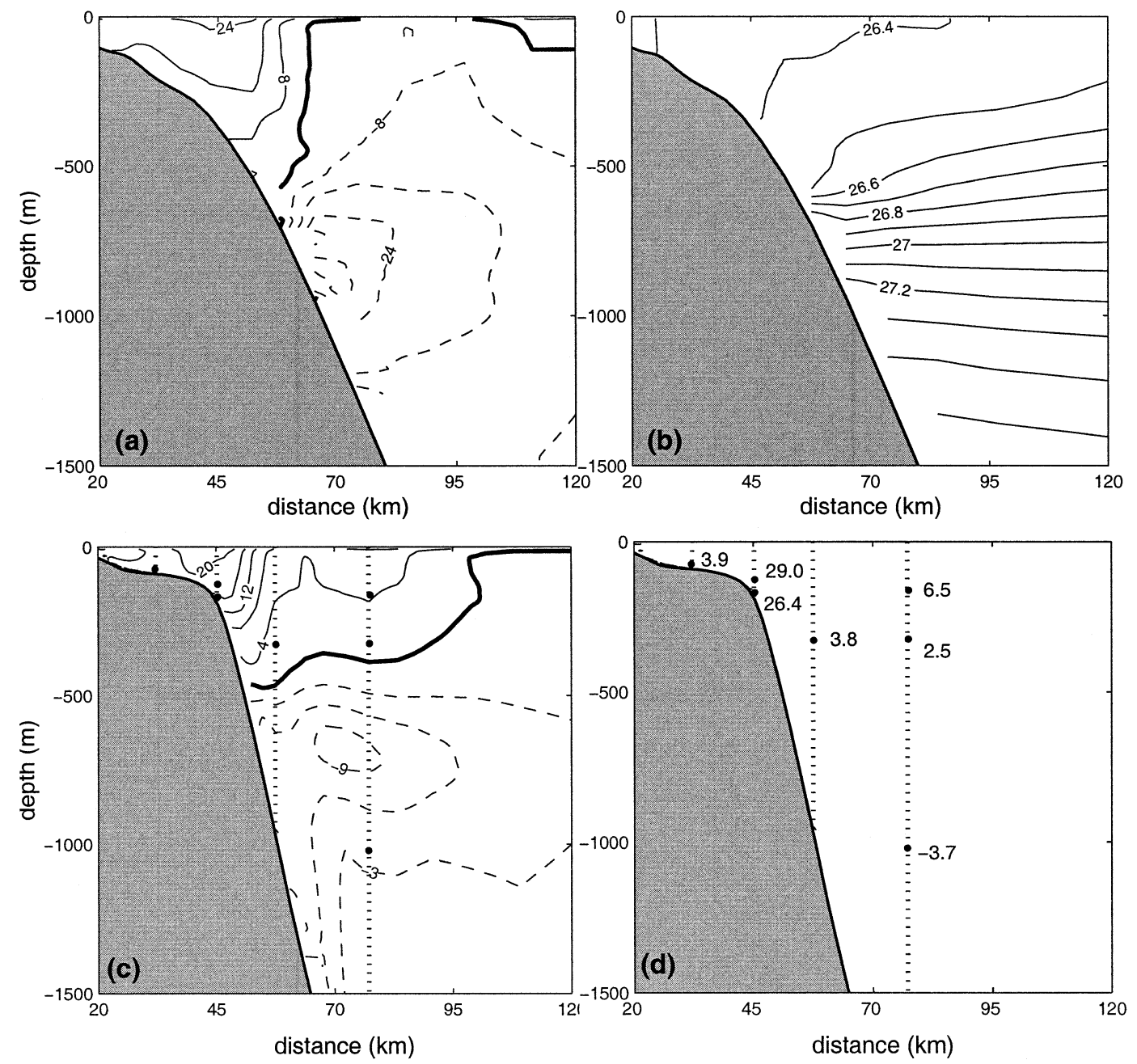

FIG. 17. (a) The alongshore velocity for the cross-shelf transect at the southern tip of Tasmania $(J=116$ in Fig. 6) at day 56 . The contour interval is $8 \mathrm{~cm} \mathrm{~s}^{-1}$. (b) As in (a) but for density (interval $0.1 \mathrm{~kg} \mathrm{~m}^{-3}$ ). (c) The alongshore velocity for the Strahan cross-shelf transect off the west coast of Tasmania ( $J=105$ in Fig. 6) and at day 56. Contour intervals are $3 \mathrm{~cm} \mathrm{~s}^{-1}$ for negative velocities and $4 \mathrm{~cm} \mathrm{~s}^{-1}$ for positive velocities. The position of the current meters is indicated by the dark circles. (d) The location of the current meters and the wintertime alongshore-averaged mean currents. Poleward velocities $\left(\mathrm{cm} \mathrm{s}^{-1}\right)$ are positive.

and data-derived means are in good agreement and indicate the existence of a northeastward jet into the strait. Farther south and near the 100-m isobath (site 1), both the model and data indicate a current of $6 \mathrm{~cm} \mathrm{~s}^{-1}$ that is directed to the east-southeast.

\section{b. The shelf circulation}

At the southern tip of Tasmania (Fig. 17a), the CC and FC have magnitudes of up to 24 and $32 \mathrm{~cm} \mathrm{~s}^{-1}$, respectively. The density field (Fig. 17b) is downwelled to depths of $500 \mathrm{~m}$ and upwelled at depths of $1000 \mathrm{~m}$. These results are consistent with the hydrographic survey of Rintoul and Sokolov (2001) and also the CARS data. The deep downwelling is likely the result of coastal downwelling and the Ekman pumping, which from Trenberth et al. (1989) is up to $14 \mathrm{~m} \mathrm{month}^{-1}$ and largest for the region. The circulation at $600 \mathrm{~m}$ for the region generally shows that the FC is again largely confined to lie inshore of the 4000-m isobath and with speeds of up to $10 \mathrm{~cm} \mathrm{~s}^{-1}$. In addition, the FC off the west Tasmanian coast results in part from a bifurcation of the Tasman outflow, as illustrated by the schematic in Fig. 1.

There are two sets of current-meter observations with which the model results can be compared and which indicate ENSO related effects. During the 1997 El Niño austral winter, moored ADCP results (Cresswell 2000) were obtained close to the Strahan section shown in Fig. 6. These data indicate depth-independent flow with mean poleward speeds of $2 \mathrm{~cm} \mathrm{~s}^{-1}$ over the $100-\mathrm{m}$ isobath (mooring R1) and $10 \mathrm{~cm} \mathrm{~s}^{-1}$ over the $(188 \mathrm{~m})$ shelf break (mooring R2). These mean currents are notably smaller than those inferred from current-meter data (Lyne and Thresher 1994) obtained during the La Niña 
winter of 1988 and displayed in Figs. 17c, 17d. For the inner site over the $93-\mathrm{m}$ isobath, the poleward mean is small $\left(4 \mathrm{~cm} \mathrm{~s}^{-1}\right)$, while for the shelf break (moorings S117U, S117L, isobath $200 \mathrm{~m}$ ), the poleward mean is much larger (26-29 $\left.\mathrm{cm} \mathrm{s}^{-1}\right)$ than that obtained in 1997. The differences may be due to ENSO events.

The model results over the shelf break (see Fig. 17c and Table 1) indicate poleward speeds of $17-19 \mathrm{~cm} \mathrm{~s}^{-1}$ that lie between the 1988 and 1997 values. The much weaker currents observed farther inshore over the 100$\mathrm{m}$ isobath are not at all reproduced by the model. A possible explanation for this is that the light freshwater outflow from Maquarie Harbour (40 km to the north) leads to an onshore pressure gradient that opposes that of the poleward current.

At the shelf break and farther offshore, the alongshore speeds of the model and observations are in reasonable agreement (Figs. 17c,d). The offshore extension of the $\mathrm{ZC}$ to distances of $50 \mathrm{~km}$ from the shelf break and depths of $400 \mathrm{~m}$ is supported by the observations obtained over the 1000- and 2040-m isobaths: the poleward currents of the model are in very good agreement with the observed speeds of 3 and $7 \mathrm{~cm} \mathrm{~s}^{-1}$. Moreover, at the deepest mooring $(\mathrm{S} 115 \mathrm{~L})$ the model is in very good agreement with the observed $4 \mathrm{~cm} \mathrm{~s}^{-1}$ northward FC.

\section{c. Transports}

For the west Tasmanian shelf transect $(J=105)$, the $\mathrm{CC}$ transport is reduced to $0.8 \mathrm{~Sv}$ over that at Kangaroo Island (Table 2) since the strait absorbs $0.95 \mathrm{~Sv}$. The alongshore component of the wind stress is similar to that off Robe (Fig. 4) and leads to an increase in the transport of the CC $(1.4 \mathrm{~Sv})$ off the southern tip of Tasmania $(J=116)$.

The westward transport through this transect is large and near $13 \mathrm{~Sv}$. The transport here is part of the Tasman outflow and within the range $(-5,21)$ Sv estimated by Rintoul and Sokolov (2001) from hydrographic data and a 2000-dbar reference level. As noted, the outflow bifurcates, as shown in Fig. 1, and drives an equatorward current of $4.3 \mathrm{~Sv}$ along the western shelf slope of Tasmania. For convenience, we have called this the FC, although it cannot be driven by the equatorward Sverdrup transport since the shelf is largely meridional in orientation.

\section{Summary and discussion}

The model results and observations indicate that a steady wintertime $\mathrm{CC}$ flows from Cape Leeuwin to the southern tip of Tasmania. The origin of the current varies. In the far west, the current is dominated by the inflow of the Leeuwin Current. Farther to the east, the current is driven by zonal winds and pressure gradients that arise from light water that is downwelled over the shelf break. Off the Eyre Peninsula, these pressure gradients, local winds, and the Leeuwin Current were shown to respectively drive about $38 \%, 47 \%$, and $18 \%$ of the shelf circulation. The model shelf currents off the gulfs were also in good agreement with observations.

Off Tasmania, the $\mathrm{CC}$ is known as the Zeehan Current, and over the shelf break and farther offshore, the model results are in good agreement with observations and replicate the offshore spreading and magnitude of the Zeehan Current.

The circulation within Bass Strait was also determined and found to be in reasonable agreement with observations. Two simple models were developed to show that about $30 \%$ of the transport through the strait is driven by local winds with much of the remainder driven by the $\mathrm{CC}$ on the west Victorian shelf. A feature of these solutions is that they 1) predict the existence of a jet near the northwest tip of Tasmania and 2) show that sea level on the east Tasmanian shelf controls the transport through the strait (see also Garrett and Toulany 1982). Higher sea level leads to a smaller transport. This and different local winds may explain the discrepancy between the model transport $(0.95 \mathrm{~Sv})$ and that inferred from observations (0.5 Sv) by Baines et al. (1991).

Interannual variations also appear to exist in the shelf current data and may be due to ENSO events. During El Niño austral winters, the data indicate the shelf currents to be weaker and sea level to be lower (Pariwono et al. 1986). The Trenberth et al. (1989) winds adopted represent an average over years 1980-86. During this period ENSO events occur, but little interannual variability was found in the wind fields for the region of study here. It is possible then that the weaker currents may arise from the lowering of sea level in the west Pacific and subsequent propagation around Australia's shelves (Clarke and Van Gorder 1994). The current data examined here suggest that ENSO-related effects may be important.

The positive wind stress curl in the southern ocean also drives an equatorward Sverdrup transport that leads to the FC and upwelling of the deep $(600 \mathrm{~m})$ thermocline (Middleton and Cirano 2002). This current is centered within the permanent thermocline (depth $600 \mathrm{~m}$ ) and flows from the west coast of Tasmania to Esperance with speeds of up to $10 \mathrm{~cm} \mathrm{~s}^{-1}$. In the far west, the transport is around $7 \mathrm{~Sv}$ and likely feeds the Leeuwin Undercurrent observed on the western shelf slope of Australia (Cresswell and Peterson 1993). Off Tasmania, it is fed by a northward arm of the Tasman outflow. In reality, the magnitude of the Tasman outflow $[(-5,21)$ $\mathrm{Sv}$ ] appears to depend on the location of the Pacific subtropical gyre (Rintoul and Sokolov 2001), and so it, and the FC off Tasmania, may vary in magnitude on an interannual basis. Observations of the FC during summer are summarized by Middleton and Platov (2003). For the winter period, the only observations we are aware of that support its existence are the associated upwelling of the permanent thermocline and the northward mean current $\left(4 \mathrm{~cm} \mathrm{~s}^{-1}\right)$ observed off Strahan at a depth of $995 \mathrm{~m}$. 
The regional model developed here adopts the winteraveraged OCCAM transports along open boundaries and the thermohaline fields throughout the domain. What advances then does the model here make over the circulation in OCCAM? As shown in the appendix, the most significant advance is the superior topography and finer resolution. In OCCAM the shelf topography contains numerous errors and is poorly resolved over the $14^{\circ}$ grid adopted. Unrealistic shelf currents result at a number of locations. In addition, the monthly mean winds used to force OCCAM are weaker than those used here and lead to much weaker currents. The currents determined here are in generally good agreement with observations.

One feature common to both models is the development of a sequence of weak high and low pressure eddies between the Eyre Peninsula and Tasmania. The cause of these eddies is almost certainly baroclinic instability, although there are only limited data to support their existence. Moreover, since the OCCAM shelf currents are poorly modeled, the existence of eddies at these sites is open to question. Indeed, this points to the main deficiency in the regional model- the density field and dense water formation.

A sensitivity study was made to evaluate the effects of the latter, which is known to be important within Spencer Gulf and the Coorong. The surface fluxes of heat and freshwater are of dubious quality for this region. Nonetheless, in qualitative agreement with observations (Godfrey et al. 1986), dense water within the Gulf was found to cascade to depths of more than 200 $\mathrm{m}$ and to spread offshore. The dense water formed near the coast also led to an increase in the $\mathrm{CC}$ by up to 5 $\mathrm{cm} \mathrm{s}^{-1}$. Notably, the pattern of shelf circulation was almost identical to that found in the absence of dense water formation. A deficiency of these results, however, was that the cooling led to surface mixed layers that were up to $500 \mathrm{~m}$ thick, or 2 times that found in the basic case and CARS data.

As we have shown, the circulation is determined by a number of quite different forcing mechanisms. The density field is generally important and an improvement would be the (successful) adoption of the CARS hydrographic data into any future model. Within the western half of the bight, the Leeuwin Current is important to the shelf circulation. Annual variations in the transport of this current may exist, and the boundary condition here might be improved by monitoring the shelf circulation using an array of bottom pressure gauges and current profilers.

Between the gulfs and Bass Strait, winds and dense water formation are most important to the shelf circulation. Improved surface fluxes for the former are needed and any model should accurately resolve regions of shallow water where dense water formation will be largest. The domain for a high-resolution model here could just encompass the region between the midbight and the west Victorian shelf since the circulation is little effected by the Leeuwin Current or that around Bass Strait.

For the shelf west of Tasmania, the circulation is affected by the winds and transport through Bass Strait. The latter is in turn affected by sea level (and currents) on the east Tasmanian shelf. The transport through Bass Strait (and model boundary condition) might be closed by appealing to sea level data obtained on either side of the strait. The shelf circulation off Robe is also important to that off west Tasmania, and this could be an additional site of bottom-moored pressure gauges and current profilers.

At depths between 500 and $1500 \mathrm{~m}$, the results here indicate the existence of the FC. As noted, the Tasman outflow may vary and the FC off Strahan be smaller. The FC does not seem to impact on the shelf circulation, although the associated onshore pressure gradient may be expected to lead to upwelling in the ubiquitous canyons of the region (e.g., Klinck 1996). Observations of the FC off Albany, Robe, and Strahan would again help in closing open boundary conditions for future model studies.

Acknowledgments. Mauro Cirano was supported by a Brazilian CNPq PhD scholarship, 200108/96-4, and the project by an Australian Research Council Grant A39700800 and the Australian Partnership for Advanced Computing. We thank AGSO and the CSIRO for the topographic and CARS data and Vince Lyne, Peter Baines and George Cresswell (CSIRO) for making their current-meter data available. We also thank the two anonymous referees for their thoughtful comments.

\section{APPENDIX}

\section{A Comparison with OCCAM and Cause of the Eddy Field}

The OCCAM horizontal circulation at the 30-m depth is presented in Fig. A1 and errors in the topography and shelf circulation are evident. The shelf depth to the west and east of Kangaroo Island is less than $30 \mathrm{~m}$ and not $50-100 \mathrm{~m}$ as indicated by the AGSO topography. In addition, three subsurface "seamounts" are located on the shelf to the west of the Eyre Peninsula (indicated by arrows). The depth of these features is $30-60 \mathrm{~m}$ while the actual water depth is around $100 \mathrm{~m}$. In addition, the coastal depths within the bight and off Robe are artificially deep (50-200 m). The western mouth of Bass Strait is also less than $30 \mathrm{~m}$ and much shallower than the actual water depth of $60 \mathrm{~m}$.

The shelf current field is also much weaker $(5-10 \mathrm{~cm}$ $\mathrm{s}^{-1}$ ) than that found in the regional model and in the observations. The FC in OCCAM (not shown) is also about one-half of that shown in Fig. 8. The reason for the weaker shelf currents is twofold. First, the OCCAM coastal depths within the bight and off Robe are artificially deep (50-200 m), and so currents will be weaker. 


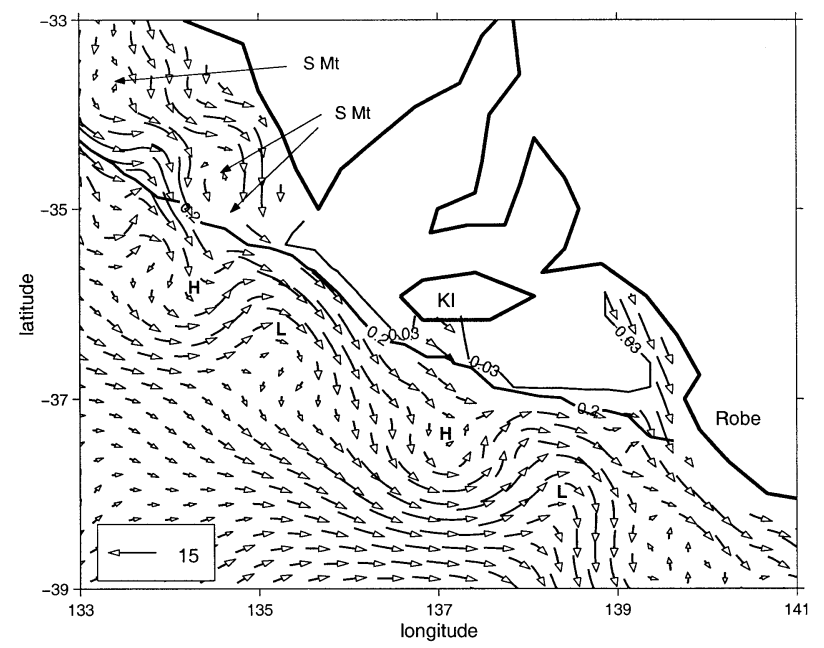

FIG. A1. The OCCAM velocity field at a depth of $30 \mathrm{~m}$ and averaged over winter. A vector of length $15 \mathrm{~cm} \mathrm{~s}^{-1}$ is indicated. The solid lines denote the $0.03 \mathrm{~km}(30 \mathrm{~m})$ and $0.2 \mathrm{~km}(200 \mathrm{~m})$ isobaths. The locations of three unrealistic seamounts (S Mt) are indicated and the water depth to the east and west of Kangaroo Island is unrealistically less than $30 \mathrm{~m}$. The locations of several high $(\mathrm{H})$ and low (L) pressure eddies are indicated.

Second, the Siefridt and Barnier (1993) wind stress adopted in OCCAM is weaker than the Trenberth et al. (1989) climatology used here. Between the bight and Robe, the Siefridt alongshore component of stress is about $0.05 \mathrm{~Pa}$. The Trenberth stress is larger and increases from $0.075 \mathrm{~Pa}$ within the bight to $0.1 \mathrm{~Pa}$ off Robe. Stronger currents are therefore found in the regional model. In addition, the wind stress curl of the Siefridt winds is also smaller than Trenberth's leading to a smaller Sverdrup transport and smaller FC. At $39^{\circ} \mathrm{S}$ (and between $122^{\circ}$ and $140^{\circ} \mathrm{E}$ ), the Siefridt and Trenberth Sverdrup transports are 4.3 and $5.7 \mathrm{~Sv}$.

As shown in Figs. 7 and A1, eddies are found both in the OCCAM and regional model circulation and at similar locations. Baroclinic instability is most likely important to the growth of the eddies in both models. Using the instability model of Gill et al. (1974), the growth rates were determined for several slope sites using the OCCAM density field. The fastest growing disturbance had a wavelength of about $60 \mathrm{~km}$ ( $e$-folding time scale 10 days). The time scale for the $250-\mathrm{km}$ wavelength was found to be 25 days. The regional model eddies are found to grow to a quasi-steady state over 36 days or so, which is crudely consistent with the $e$ folding scale of 25 days. The 36-day period is also much larger than expected for geostrophic adjustment.

The question is, What sets the location of the eddies in the regional model and OCCAM? For the regional model, the answer is given by an experiment made with a coastal wall along the $200-\mathrm{m}$ isobath and between the Eyre Peninsula and the southern tip of Tasmania. The wall minimizes the effects of coastal topographic variations. Surprisingly, results so obtained (with wind forcing) show a pattern of eddies similar to the basic case (Figs. 7 and 11). Thus, the eddy locations are largely set by the OCCAM density field. This is supported by the adjustment solutions in Fig. 10, where the OCCAM density is the sole forcing mechanism in the model.

What then determines the locations of the eddies in the OCCAM? Other studies (e.g., Ikeda and Emery 1984; Batteen 1997) have shown that high and low pressure eddies can be generated by the production of vorticity that accompanies flow driven across the slope by topographic irregularities. For the OCCAM, offshore flow occurs in the vicinity of the Eyre Peninsula, Kangaroo Island, and Robe (Fig. A1). The OCCAM circulation here is not particularly realistic although the regional model also indicates an offshore flow near these sites (Fig. 7). At these sites, high pressure eddies are generated through the production of anticyclonic vorticity that accompanies vortex squashing. The squashing results from the offshore flow into an isopycnal field that converges away from the shelf (e.g., Fig. 12b).

Between Robe and Kangaroo Island, both the OC$\mathrm{CAM}$ and regional model show the development of a low pressure eddy off Robe. In both cases, the eddy here is initially triggered by the overshoot of the FC into deep water where the shelf rapidly narrows (see the 4000-m isobath in Fig. 8). Cyclonic vorticity is then produced.

Evidence for these quasi-steady eddies is limited. Ridgway and Condie (2003, manuscript submitted to $J$. Geophys. Res.) have presented maps of monthly sea level for the region based upon a combination of altimeter and hydrographic data. For the month of July, these maps show a wavelike sequence of highs and lows between the Eyre Peninsula and Bass Strait. The locations of these features is just that found here in Fig. 10. A quasi-stationary, anticyclonic eddy south of Kangaroo Island is also found in drifter trajectories (Godfrey et al. 1986; Hahn 1986). However, in light of the lack of compelling evidence and given the approximate nature of the OCCAM shelf circulation, we conclude that the existence of the eddy field remains open to question.

\section{REFERENCES}

Baines, P. G., R. J. Edwards, and C. B. Fandry, 1983: Observations of a new baroclinic current along the western continental slope of Bass Strait. Aust. J. Mar. Freshwater Res., 34, 155-157.

_, G. Hubbert, and S. Power, 1991: Fluid transport through Bass Strait. Cont. Shelf Res., 11, 269-293.

Batteen, M. L., 1997: Wind-forced modeling studies of currents, meanders, and eddies in the California Current system. J. Geophys. Res., 102, 985-1010.

Blumberg, A. F., and G. L. Mellor, 1987: A description of a threedimensional coastal ocean circulation model. Three-Dimensional Coastal Ocean Models, N. S. Heaps, Ed., Coastal and Estuarine Series, Vol. 4, Amer. Geophys. Union, 1-16.

Chu, P., and C. Fan, 1997: Sixth-order difference scheme for sigma coordinate ocean models. J. Phys. Oceanogr., 27, 2064-2071.

Church, J. A., and H. J. Freeland, 1987: The energy source for the 
coastal-trapped waves in the Australian coastal experiment region. J. Phys. Oceanogr., 17, 289-300.

Clarke, A. J., and S. Van Gorder, 1994: On ENSO coastal currents and sea levels. J. Phys. Oceanogr., 24, 661-680.

Cresswell, G. R., 2000: Currents of the continental shelf and upper slope of Tasmania. Pap. Proc. Roy. Soc. Tasmania, 133, 21-30. -, and J. L. Peterson, 1993: The Leeuwin Current south of western Australia. Aust. J. Mar. Freshwater Res., 44, 285-303.

da Silva, A. M., C. C. Young, and S. Levitus, 1994: Algorithms and Procedures. Vol. 1, Atlas of Surface Marine Data 1994, NOAA Atlas NESDIS 6, U.S. Department of Commerce, 84 pp.

Flather, R. A., 1988: A numerical model investigation of tides and diurnal-period continental shelf waves along Vancover Island. J. Phys. Oceanogr., 18, 115-139.

Fortunato, A. B., and A. M. Baptista, 1996: Evaluation of horizontal gradients in sigma-coordinate shallow water models. Atmos.Ocean, 34, 489-514.

Garrett, C., and B. Toulany, 1982: Sea level variability due to meteorological forcing in the northeast Gulf of St. Lawrence. $J$. Geophys. Res., 87, 1968-1978.

Gill, A. E., J. S. A. Green, and A. J. Simmons, 1974: Energy partition in the large-scale ocean circulation and the production of midocean eddies. Deep-Sea Res., 21, 499-528.

Godfrey, J. S., D. J. Vaudrey, and S. D. Hahn, 1986: Observations of the shelf-edge current south of Australia, winter 1982. J. Phys. Oceanogr., 16, 668-679.

Hahn, S. D., 1986: Physical structure of the waters of the South Australian continental shelf. Ph.D. thesis, Flinders University of South Australia, 284 pp.

Haney, R. L., 1991: On the pressure gradient force over steep topography in sigma coordinate ocean models. J. Phys. Oceanogr., 21, 610-619.

Herzfeld, M., 1997: The annual cycle of sea surface temperature in the Great Australian Bight. Progress in Oceanography, Vol. 39, Pergamon, 1-27.

Ikeda, M., and W. J. Emery, 1984: Satellite observations and modeling of meanders in the California Current system off Oregon and northern California. J. Phys. Oceanogr., 14, 1434-1450.

Josey, S. A., E. C. Kent, D. Oakley, and P. K. Taylor, 1996: A new global air-sea heat and momentum flux climatology. Int. WOCE Newsletter, No. 24, WOCE International Project Office, Southampton, United Kingdom, 3-5.

Klinck, J. M., 1996: Circulation near submarine canyons: A modeling study. J. Geophys. Res., 101, 1211-1223.

Levitus, S., and T. P. Boyer, 1994: Temperature. Vol. 4, World Ocean Atlas 1994, NOAA Atlas NESDIS 4, 117 pp.

— R. Burgett, and T. P. Boyer, 1994: Salinity. Vol. 3, World Ocean Atlas 1994, NOAA Atlas NESDIS 3, 99 pp.

Lyne, V. D., and R. E. Thresher, 1994: Dispersal and advection of macruronus novaezealandiae (Gadiformes: Merlucciidae) larvae off Tasmania: Simulation of the effects of physical forcing on larval distribution. Bio-Physics of Marine Larval Dispersal, P. W. Sammarco and M. L. Heron, Eds. Coastal and Estuarine Studies, Vol. 45, Amer. Geophys. Union, 109-136.

Mellor, G. L., 1998: User's guide for a three-dimensional, primitive equation, numerical ocean model. Program in Atmospheric and Oceanic Sciences, Princeton University, Princeton, NJ, 41 pp.

—, T. Ezer, and L.-Y. Oey, 1994: The pressure gradient conundrum of sigma coordinate ocean models. J. Atmos. Oceanic Technol., 11, 1126-1134.

, L.-Y. Oey, and T. Ezer, 1998: Sigma coordinate pressure gradients errors and the seamount problem. J. Atmos. Oceanic Technol., 15, 1122-1131.
Middleton, J. F., 2000: Wind-forced upwelling: The role of the surface mixed layer. J. Phys. Oceanogr., 30, 745-763.

_ Bass Strait. J. Phys. Oceanogr., 21, 695-708.

_ , and K. P. Black, 1994: The low frequency circulation in and around Bass Strait: A numerical study. Cont. Shelf Res., 14, $1495-1521$.

— idealised study. Applied Mathematics Rep. AMR00/21, School of Mathematics, University of New South Wales, Sydney, Australia, $8 \mathrm{pp}$.

— , and M. Cirano, 2002: A northern boundary current along Australia's southern shelves: The Flinders Current. J. Geophys. Res. 107, 3129, doi:10.1029/2000JC000701.

_ Australia's southern shelves: A numerical study. J. Phys. Oceanogr., 33, 2270-2287.

Nunes-Vaz, R. A., G. W. Lennon, and D. G. Bowees, 1990: Physical behavior of a large, negative or inverse estuary. Cont. Shelf Res., 10, 277-304.

Palma, E. D., and R. P. Matano, 1998: On the implementation of passive open boundary conditions for a general circulation model: The barotropic mode. J. Geophys. Res., 103, 1319-1341.

Pariwono, J. I., J. A. T. Bye, and G. W. Lennon, 1986: Long-period variations of sea-level in Australasia. Geophys. J. Roy. Astron. Soc., 87, 43-54.

Platov, G., and J. F. Middleton, 2000: A barotropic model of tides along Australia's southern shelves. Applied Mathematics Rep. AMR00/22, School of Mathematics, University of New South Wales, Sydney, Australia.

Provis, D. G., and G. W. Lennon, 1981: Some oceanographic measurements in the Great Australian Bight. Proc. Fifth Australian Conf. on Coastal and Ocean Engineering, Perth, Australia, The Institution of Engineers, 119-120.

Ridgway, K. R., J. R. Dunn, and J. L. Wilkin, 2002: Ocean interpolation by four-dimensional weighted least squares-Application to the waters around Australasia. J. Atmos. Oceanic Technol., 19, 1357-1375.

Rintoul, S. R., and S. Sokolov, 2001: Baroclinic transport variability of the Antarctic Circumpolar Current south of Australia (WOCE repeat section SR3). J. Geophys. Res., 106, 2815-2832.

Rochford, D. J., 1986: Seasonal changes in the distribution of Leeuwin Current waters off southern Australia. Aust. J. Mar. Freshwater Res., 37, 1-10.

Schahinger, R. B., 1987: Structure of coastal upwelling events observed off the south-east coast of South Australia during February 1983-April 1984. Aust. J. Mar. Freshwater Res., 38, 439459.

Siefridt, L., and B. Barnier, 1993: Banque de Données AVISO vent/ flux: Climatologie des analyses de surface du CEPMMT. Institut Français de Recherche pour l'exploitation de la Mer. Tech. Rep. IFREMER 911430 025, $43 \mathrm{pp}$.

Smagorinsky, J., 1963: General circulation experiments with the primitive equations. I. The basic experiment. Mon. Wea. Rev. 91, 99-164.

Song, Y. T., 1998: A general pressure gradient formulation for ocean models. Part I: Scheme design and diagnostic analysis. Mon. Wea. Rev., 126, 3213-3230.

Trenberth, K. E., J. C. Olson, and W. G. Large, 1989: A global ocean wind stress climatology based on ECMWF analyses. National Center for Atmospheric Research Tech. Rep. NCAR/TN$338+$ STR, 98 pp.

Webb, D., B. A. de Cuevas, and A. C. Coward, 1998: The first main run of the OCCAM global ocean model. Southampton Oceanography Centre, Tech. Rep. 34, 43 pp. 